\title{
A escrita da história de Marajó, em Dalcídio Jurandir
} Power relations and mediation procedures in Marajó, availed by Dalcídio

\section{Jurandir}

Willi Bolle - Professor do Programa de Pós-Graduação em literatura da Universidade de São Paulo. Autor de Fisiognomia da Metrópole Moderna (1994; $3^{\mathrm{a}}$ ed., em preparação), grandesertão.br - O romance de formação do Brasil (2004), e co-organizador, com Edna Castro e Marcel Vejmelka, de Amarônia - região universal e teatro do mundo, Editora Globo, 2010. E-mail: willibolle@yahoo.com.br

\section{Resumo}

Dentre as dez obras do Ciclo do Extremo Norte (1941-1978), de Dalcídio Jurandir, focalizamos aqui o romance Marajó (1947), por ser o que contém a maior diversidade de informações sobre a cultura cabocla. Esse romance semi documental é uma modalidade de escrita da história, ao mesmo tempo em que o seu componente ficcional, que inclui uma trama erótica, marca uma diferença. $\mathrm{Na}$ sociedade retratada são realçadas as relações de poder, que examinamos do lado dos senhores e do lado dos pobres, incluindo as formas de resistência destes. O episódio central da obra é um utópico projeto de melhoria social, empreendido pelo protagonista, o filho rebelde de um latifundiário. Com essa utopia e a opção do romancista por essa figura de mediação entre ricos e pobres - no plano da ação narrada, como na tradução da cultura cabocla para o código do leitor culto - o romancista apresenta um tema que é relevante tanto para as ciências sociais quanto para os estudos literários e culturais.

\section{Palavras-chave}

Marajó. Dalcídio Jurandir. Cultura cabocla. Relações de poder. Utopia. Procedimentos de mediação.

\begin{abstract}
Of the ten novels of Dalcídio Jurandir's Amazon Cycle (1941-1978), we focus on Marajó (1947), as it contains the greatest diversity of information on Caboclo culture. This semi-documentary novel is a kind of writing of history, but it also has fictional elements such as an erotic plot. In the description of local society relations of power, which are studied both from the side of the masters and the poor, including their forms of resistance, are emphasized. The central episode of the novel is a Utopian project of social improvement, undertaken by the protagonist, the rebellious son of a large landowner. With the Utopia and the choice of the novelist of this character as a mediator between the rich and the poor, both in the plot and the "translation" of Caboclo culture to the code of the literate people, Jurandir proposes a subject which is important both for social sciences and literary and cultural studies.
\end{abstract}

\section{Keywords}

Marajó. Dalcídio Jurandir. Caboclo culture. Relations of power. Utopia. Techniques of mediation. 


\section{INTRODUÇÃO: O ROMANCE COMO FORMA DE PESQUISA}

Uma obra fundamental para o conhecimento da Amazônia no século XX é o "Ciclo do Extremo Norte", do escritor paraense Dalcídio Jurandir (1909-1979), que trata de Belém, Marajó e do Baixo Amazonas. Esse conjunto de dez romances, de quase 3.000 páginas, oferece uma apresentação da história e da cultura cotidianas dos habitantes da região, sobretudo das camadas mais baixas, que é exemplar em termos de abrangência e minuciosidade. Num enfoque crítico, o romancista mostra a continuidade de estruturas coloniais em pleno século XX. Em contrapartida, e essa é uma qualidade especial do seu projeto literário e político, ele concede um amplo espaço às falas das pessoas do povo, que assim se fazem presentes com a sua voz na esfera pública. Dessa forma, o escritor procura utilizar a literatura como um meio de resistência e de transformação histórica.

Do conjunto da obra do escritor, focalizaremos aqui o romance Marajó, que fornece um retrato da ilha homônima. Marajó, a maior ilha fluvial do mundo, situada em frente a Belém e dispondo de múltiplos recursos naturais, firmou-se desde o século XVIII como "a dispensa da capital" do Pará (SPIX; MARTIUS, 1981, p. 24). Enquanto a metade sudoeste da ilha é coberta de florestas e utilizada sobretudo para a extração de madeira e a colheita de frutas silvestres, a metade nordeste é uma extensa área de pastagens e criação de gado. Os municípios de Ponta de Pedras (onde Dalcídio Jurandir nasceu) e Cachoeira do Arari (onde ele passou a maior parte de sua infância) são os cenários de seus primeiros três romances - Chove nos campos de Cachoeira (1941), Marajó (1947) e Três casas e um rio (1958) -, dos quais escolhemos aqui o segundo por várias razões.

Dentre os dez romances do Ciclo, Marajó é o que contém a maior diversidade de informações sobre a cultura dos caboclos. ${ }^{1}$ Além de ser uma obra ficcional, é também a mais "documental" do autor, e com isso, um bom exemplo do romance como "forma de pesquisa e descoberta do país" (CANDIDO, 1981, II, p. 112). Com isso, Marajó aproxima-se bastante dos estudos historiográficos e sociais, o que é confirmado pelo interesse que essa obra tem despertado em historiadores e cientistas sociais. Pode até se dizer - e esta é a nossa hipótese de trabalho - que Dalcídio Jurandir se propôs nesse romance nada mais nada menos do que escrever uma história de Marajó. Procuraremos mostrar detalhadamente como ele constrói

1 Com as referências aos municípios de Anajás e Santa Cruz (no centro), Chaves (no norte da ilha), Breves (no sudoeste), Muaná, Ponta de Pedras e Cachoeira do Arari (no sul e no sudeste) e Salvaterra e Soure (no leste) são representados nove dos (atuais) doze municípios de Marajó, de modo que o retrato fornecido nesse romance pode ser considerado como representativo da ilha inteira. 
essa história em sua narrativa, com atenção também para as diferenças do gênero romance em relação à historiografia.

Em vez de apresentar a história do Marajó de modo cronológico, conceitual e sistemático, como uma pesquisa historiográfica, o romance evoca os fatos mais significativos através da ordem casual de rememorações espontâneas, que são inseridas na narrativa em forma de fragmentos. Assim, temos algumas referências aos primeiros colonizadores do arquipélago, nos séculos XVII e início do XVIII: os padres jesuítas, que instalaram engenhos e fazendas de gado, onde usavam como escravos os índios que eles caçavam e os negros trazidos da África. Há também informações sobre a segunda fase da colonização, a partir de meados do século XVIII, quando os jesuítas foram expulsos pelo governo português e substituídos por latifundiários leigos, os quais, apesar do movimento da Cabanagem (18351840), que foi derrotado, e da Abolição (1888), continuavam o seu domínio sobre a ilha, com estruturas coloniais, que eles mantiveram até o início do século XX.

Esse background histórico permite ao leitor situar-se melhor na época em que se passa o romance: entre 1915 e 1920, um tempo marcado pelo colapso da borracha e o declínio da economia, com algumas tentativas de reestruturação. $\mathrm{Na}$ ilha do Marajó houve então uma escassez de empregos e um descontentamento da população com as condições de trabalho. Resultou daí, como fenômeno histórico mais significativo daquele período, o êxodo da mão de obra. Através do olhar de um dos personagens é apresentado "o povo esvaziando Ponta de Pedras, em lenta e triste migração" (MAR, p. 68). ${ }^{2}$ A preocupação geral é: quais são nessa situação as oportunidades de emprego? "Trabalho mais não havia", por isso "os homens iam para Abaeté, Tocantins, para os garimpos, escolhiam as olarias, serrarias, a pesca na Contra-Costa, a vida dos barcos, partiam para as Ilhas" (ibid.). O destino principal dos migrantes é a grande cidade da região: "Em Belém, era o apito das fábricas chamando pessoal de todas as vilas abandonadas do interior" (ibid.). O tema da migração está presente no ciclo inteiro de Dalcídio Jurandir, sendo que a metade de seus romances tem como cenário a periferia de Belém. Em Marajó, o autor se detém na descrição das condições de trabalho dos que permanecem na ilha.

Em sua apresentação da sociedade marajoara, Dalcídio Jurandir realça a polarização entre ricos e pobres, isto é, as relações de poder entre os proprietários, latifundiários e comerciantes - os "brancos", que lidam com bens e dinheiro e ocupam os cargos públicos - e, por outro lado, os caboclos, que são os comandados, a mão-de-obra, os trabalhadores braçais. Uma classe média praticamente não existe (cf. FURTADO, 2007, p. 116). O romance Marajó apresenta os processos econômicos, políticos e sociais na perspectiva micro-histórica de uma família,

2 A abreviatura MAR refere-se daqui em diante ao romance Marajó, 4. ed. (2008). 
no caso, a família do latifundiário Coronel Coutinho, com destaque especial para o seu filho, Missunga. No relacionamento do Coronel com o seu entorno social encontram-se resumidas todas as estruturas do sistema colonial, inclusive fragmentos sobre as fases anteriores da colonização.

Para que o leitor possa acompanhar melhor esta análise do romance Marajó (de 53 capítulos e 431 páginas: MAR, p. 31-461), é útil começar por um resumo da trama. Podemos distinguir sete fases.

1. (capítulos 1-3) No início é apresentado o retrato do Coronel Coutinho, com sua família, suas propriedades e seu poder: ele "sabia dominar os sítios e a vila de Ponta de Pedras, os lagos e as fazendas de Cachoeira". Sua esposa, d. Branca, também de uma família de fazendeiros, morreu, e o Coronel desde então, convive com uma outra mulher, a jovem d. Ermelinda. No limiar da velhice, ele quer aposentar-se na sua casa de campo em Paricatuba (em frente da vila de Ponta de Pedras, do outro lado do rio Marajó-açu), desejando que Missunga, seu único filho, assuma os negócios. Este, porém, se mostra rebelde com relação ao pai: não concluiu seus estudos em Belém e no Rio de Janeiro, mas entregou-se às farras; "o mal da fartura" o fez voltar para a ilha, onde passara a infância. Aqui ele leva uma vida de ocioso, passando o tempo caçando e interessando-se por várias moças caboclas, notadamente Alaíde, Guíta e Orminda.

2. (capítulos 4-7) Com Missunga como observador participante, e a partir de pontos de encontro como a loja do seu pai, a do comerciante Calilo, a rua, a igreja e alguns barracos de pobres, esboçam-se tableaux sociológicos e antropológicos da população da vila (cf. MARIN, 2006a): antigas escravas, que em sua juventude tiveram relações sexuais e filhos com o Coronel; pequenos sitiantes, que se endividaram e com isso acabam perdendo suas terras; homens e mulheres que ganham a vida com fornecimentos de lenha e açaí; rezadores, que procuram consolo na religião; e muitos desempregados que abandonam a ilha, para procurar emprego em Belém.

3. (capítulos 8-27) O episódio central do romance é um projeto de colonização idealizado por Missunga durante suas andanças, observações e aventuras eróticas, uma plantação à qual ele dá o nome de Felicidade. Essa colônia agrária, que ele funda em terras que foram desapropriadas pelo seu pai, deverá servir para o bem da população. De toda parte afluem os desempregados e os famintos com suas famílias. Ora, esse empreendimento é improvisado por Missunga de maneira leviana, faltam todas as estruturas básicas: uma boa administração, ferramentas, sementes, um serviço de saúde e, sobretudo, um real diálogo com os trabalhadores e um interesse verdadeiro por suas necessidades. Missunga deixa simplesmente acontecerem as coisas que ele iniciou, e passa o tempo na rede com 
Alaíde (ela, sim, se engaja no trabalho social) e em aventuras eróticas paralelas e escondidas com Guíta. Quando fica sabendo que Alaíde está esperando um filho dele, ele a obriga a fazer o aborto. Nessas circunstâncias, o projeto Felicidade acaba fracassando e termina com a expulsão dos trabalhadores.

4. (capítulos 28-36) Segue-se uma viagem de Missunga com o seu pai até as fazendas deste ao longo do rio Arari, entre a vila de Cachoeira e o lago Arari. As observações feitas nesses lugares constituem um contraponto realista à pseudoutopia Felicidade. O Coronel Coutinho e o seu primo, o capitão Guilherme, são retratados como latifundiários exploradores. $\mathrm{O}$ administrador das fazendas do Coronel é o severo Manuel Raimundo, que extrai dos vaqueiros o máximo de trabalho, ao mesmo tempo em que força a redução dos custos. Da mesma maneira age o capitão Guilherme, que deixa seus vaqueiros passarem fome. Ambos os latifundiários são também, juntamente com um comerciante, os donos dos rios e lagos, proibindo os moradores de pescar para o seu próprio sustento, obrigandoos a comprar sua comida na loja, mantendo-os, assim, num sistema de dívidas. Essa descrição das condições econômicas e de dominação é complementada por observações da vida cotidiana dos vaqueiros e dos pescadores, de seus costumes e de suas festas, incluindo as práticas de uma pajé e as chulas ou canções críticas do vaqueiro Ramiro, que vive um breve romance com a bela Orminda.

5. (capítulos 37-45). Na volta de Missunga para Ponta de Pedras focaliza-se a sua relação com Guíta e com Alaíde. Na ida, ele participara ao pai o seu plano de escolher Guíta como a sua companheira, o que o Coronel desaprovou, por ela não ser da mesma condição social. A questão se resolve de maneira trágica, pois Guíta sofre um acidente fatal. Missunga empreende, então, uma viagem de barco ao longo da costa leste da ilha com Alaíde - usando-a como consolo pela perda da outra. Temporariamente, retiram-se para um barraco. O Coronel vai atrás do filho, intimando-o a voltar, com a ameaça de o deserdar.

6. (capítulos 46 e 47). A notícia da morte do Coronel provoca no seu filho uma mudança radical. O seu "único sentimento real" passa a ser o da posse da herança. Ao mesmo tempo, ele liquida com todos as suas demais emoções e começa a dedicar-se à administração de seus bens, secundado pelo administrador Manuel Raimundo. Ele muda, inclusive, de nome, chamando-se agora "Dr. Manuel Coutinho". A entrada na posse, a administração de seus bens e o tratamento dos seus empregados equivalem à manutenção das velhas estruturas.

7. (capítulos 48-53). Os últimos capítulos do romance convergem para um retrato da vila de Ponta de Pedras, que é cada vez mais abandonada pelos seus habitantes, e de onde se retirou também Manuel Coutinho, que se mudou para Belém e Rio de Janeiro. Descreve-se a situação difícil dos que ficam e as 
suas tentativas de encontrar uma saída: o desempregado, que perdera o seu sítio, afunda na miséria total; o vaqueiro andante sobrevive graças às suas canções, a trabalhos temporários e pequenos furtos; quanto à Alaíde, em vez de resignar-se como a maioria das caboclas, ela resolve migrar para Belém em busca de trabalho.

$\mathrm{Na}$ trama desse romance em forma de micro-história, estão contidos vários elementos que permitem situá-lo no contexto da história colonial. Assim, por exemplo, através da rememoração de d. Branca, a falecida esposa do Coronel Coutinho, são evocados elementos do ciclo da cana de açúcar, que foi importante no período inicial da colonização. "Para fazer o gosto da senhora" - d. Branca era filha de dono de engenho - o Coronel tinha instalado, durante os primeiros anos de seu casamento, um engenho, que ele fechou depois. D. Branca procura rememorar esse passado com visitas às "ruínas de engenhos que os frades coloniais deixaram", em Santana, Araquiçaua e no Alto Arari (MAR, p. 54). Outro exemplo é a extensão das terras que pertencem ao Coronel. Na visita de Missunga aos "campos do seu pai", ele vai conhecendo "a grande propriedade ao longo da ilha [...], Chaves, Anajás, Soure, Cachoeira” (p. 274). Como esses são os municípios que constituem a área principal de criação de gado, o Coronel, na qualidade de "maior fazendeiro do Arari” (p. 302), é dono de parte considerável da ilha. Quando o herdeiro vai fazer o inventário dos domínios do seu pai no rio Arari, é um percurso de "duas horas e pico de lancha. Mundão" (p. 398). Temos aqui, sem dúvida, o uso amplificador da ficção literária; mas uma vez que o romancista quer mostrar a continuidade das estruturas coloniais, vale lembrar que no início da colonização as fazendas do Marajó estavam nas mãos de apenas quatro grandes proprietários (cf. MIRANDA NETO, 2005, p. 178). Um terceiro exemplo é a dimensão histórica da exploração da mão-de-obra, sobre a qual informam alguns fragmentos inseridos ao longo da narrativa, que falam da caça aos índios, do tratamento dos escravos e dos cabanos - três temas controversos, conforme o ponto de vista de quem narra a história. Enquanto o piloto Pedro Mala Real critica a crueldade dos frades colonizadores - que "amarravam os escravos [...] no tronco espinhento do tucumãzeiro e caçavam índio como se caça onça" -, além de defender a revolta dos cabanos (MAR, p. 367), o Coronel Coutinho realça os feitos gloriosos do seu avô, "português da gema", que veio "com a tradição do Rei e da Corte" e "domou índios", além de "lut[ar] com os cabanos, essa página negra da história paraense" (p. 186). Finalmente, o que evidencia a continuidade das estruturas coloniais até o tempo presente, é a relação entre as gerações, concretamente, entre o Coronel e o seu filho. Embora Missunga, num primeiro momento, se apresente como crítico do pai e idealizador de um projeto que parece superar as velhas estruturas, o conjunto de sua trajetória, sobretudo o seu comportamento como herdeiro das 
propriedades do pai, juntamente com a adoção simbólica do seu nome de família, deixa claro que "nada vai mudar" (p. 397).

O que diferencia essencialmente o gênero romance de uma pesquisa historiográfica? Além da liberdade da invenção ficcional, um distintivo são os componentes sentimentais, inclusive eróticos. Este é também o caso de Marajó, onde o romance de Missunga com as caboclas Alaíde e Guíta é um dos dois eixos da narração, com um início, um auge, um declínio e um encerramento definitivo. Paralelamente a essa trama erótico-sentimental é montado um segundo eixo da ação: a trajetória de Missunga como ator de uma história econômica e social. Ela começa com o seu interesse pela vida cotidiana dos caboclos e atinge o ápice no projeto da colônia agrária Felicidade. Depois do fracasso dessa utopia, passa para o primeiro plano o contato do protagonista com a realidade prosaica das fazendas. Num primeiro momento, ele é um observador crítico da exploração dos trabalhadores que ali impera; num segundo momento, como herdeiro do pai e dono do poder, ele passa a ser o principal responsável por esse estado das coisas. Portanto, a relação entre os dois eixos da narrativa é móvel: na primeira metade da história, as peripécias erótico-sentimentais atenuam a polarização entre ricos e pobres; já na segunda metade, elas sofrem o impacto dos comportamentos regidos pelos interesses do poder e se apagam.

O modo como o romancista utiliza o personagem Missunga como guia para introduzir o leitor ao universo da cultura cabocla, fazendo-o conhecer as diversas facetas do convívio e do conflito entre os donos do poder e os oprimidos, nos leva ao outro elemento diferenciador do gênero romance em comparação com uma pesquisa historiográfica. Trata-se da arte de narrar, centrada na figura do narrador, que faz a mediação entre o mundo representado e o leitor. Em todas as sociedades a literatura desempenha, além da autorreflexão, uma função de comunicação, de socialização e de mediação entre os diferentes segmentos sociais. Essa função mediadora constitui um desafio especial na sociedade brasileira, com seus fortes antagonismos entre pobres e ricos, diante do pano de fundo histórico da escravidão, como o expressa emblematicamente o título da obra de Gilberto Freyre Casa Grande \& Senzala (1933). Nesse contexto, os romances de Dalcídio Jurandir contêm muitos elementos relevantes para se estudar a questão da mediação social: tanto no nível da ação narrada (com os conflitos entre dominadores e dominados, entre ricos e pobres), quanto no nível da transposição literária da cultura iletrada dos caboclos para o código do leitor culto. Nas obras do Ciclo do Extremo Norte, a tarefa da mediação é repartida entre um narrador externo à ação e um protagonista, que é um go-between entre as classes. Em nove dos dez romances, esse protagonista mediador é o adolescente Alfredo. Somente no romance Marajó, 
o autor optou como figura mediadora pelo filho rebelde de um latifundiário. $\mathrm{O}$ estudo das questões que se colocam com essa opção é instrutivo, tanto para o conhecimento dessa obra específica, quanto para a literatura brasileira em geral. Veremos, ao longo desta análise, que Marajó não é apenas um experimento, mas também um caso exemplar em termos de mediação.

A questão da mediação literária entre as diferentes classes sociais é complexa, tanto quanto a das relações de poder, e o que ainda aumenta essa complexidade é o fato de ambas serem profundamente imbricadas. Por isso, vamos por partes.

Durante uma oficina de leitura dramática com o romance Marajó, que realizamos em 2007 em Ponta de Pedras, com professores e estudantes, estes manifestaram a sua dificuldade de entendimento do texto. Como causa principal da dificuldade foi apontada a frequente mudança do foco narrativo. Muitas vezes, o leitor fica sem saber de quem é a fala: se do narrador ou de um personagem, e também, de qual dos personagens. Acrescenta-se a isso a mescla de observações do lado de fora com mergulhos no fluxo de consciência dos personagens. Essas constatações dos participantes da oficina (cf. BOLLE, 2008) valem também com um indício da tentativa de Dalcídio Jurandir de apropriar-se do olhar dos diferentes atores sociais, que se repartem em dois grupos antagônicos: os donos do poder e os pobres.

A divisão deste ensaio em três partes (além desta Introdução) é de ordem didática. As duas partes que tratam das relações de poder envolvem sempre os dois lados ao mesmo tempo, não importa se a perspectiva é a dos senhores, ou a dos dominados. As atitudes e ações de cada uma dessas duas classes sociais implicam sempre também o antagonista. Quando tratamos dos donos do poder, não tomamos com isso o partido deles, mas procuramos descrever de quem são as falas e as opiniões manifestadas: se de um determinado personagem, do narrador dalcidiano ou do seu protagonista mediador. Além de procedimentos de desmontagem crítica, observaremos tons de denúncia e de ironia, que costumam ser formas de resistência à visão dominante da história. E quando focalizamos o lado dos pobres, importa estar atento sobretudo ao modo como a história deles é narrada pelo romancista. O que pode parecer apenas um relato de derrotas, é também uma história de lutas contra a ordem dominante, e o próprio fato de o autor dar voz aos vencidos não deixa de ser uma forma de resistência e uma vontade de mudar a escrita da história.

O fato de acoplarmos o estudo das relações de poder (nas partes I e II) ao dos procedimentos de mediação (na parte III) tem uma razão metodológica. Procuramos, com isso, superar a dicotomia entre as interpretações sociológicas, antropológicas, etnográficos e históricas, de um lado, e do outro lado, as análises 
literárias ou narratológicas. Uma tal divisão do romance de Dalcídio Jurandir em aspectos conteudísticos e aspectos formais representaria uma redução do valor cognitivo de sua obra em termos de escrita da história. Como bem observou Walter Benjamin, não existe, a rigor, uma "história literária" independente; o que existe, sim, é a literatura como parte da história geral. ${ }^{3}$ É esse tipo de elo entre a história narrada no romance e a realidade econômica e social fora dele, que faz com que a experiência protagonizada por Missunga se revista de um interesse mais geral. Notadamente o seu projeto social, a utopia ou pseudoutopia da plantação Felicidade - que, num primeiro momento, parece superar as velhas estruturas coloniais - tem valor paradigmático. Vários elementos daquela experiência podem ser transpostos para a Amazônia do início deste século XXI, ajudando a pensar projetos de modernização atualmente em curso, onde se colocam problemas de comunicação entre caboclos e profissionais vindos de fora; a questão da cidadania e dos sujeitos da história; antigas e novas estratégias de dominação e de resistência, com a das comunidades de quilombolas; e, não por último, a ideia de uma história de Marajó contada pelos caboclos, o que é sugerido em vários momentos da obra de Dalcídio Jurandir. A proposta deste ensaio é descrever as diversas características de sua escrita da história, inclusive as lições que o leitor pode tirar das ilusões e dos fracassos do protagonista.

\section{AS RELAÇÕES DE PODER - I: O LADO DOS SENHORES}

A apresentação da esfera dos senhores, ou melhor, dos "donos de gado e gente" (aqui cabe bem a formulação de Geraldo Vandré) é centrada no personagem do Coronel Coutinho. Seu retrato não pretende ser um estudo psicológico diferenciado de um indivíduo, mas é a descrição de um tipo social, o latifundiário explorador, que representa uma estrutura: daí, inclusive, alguns traços estereotipados, como é próprio dos romances de crítica social. A base do poder do Coronel é o seu patrimônio:

Quarenta mil reses [...], búfalos, a melhor cavalaria de Marajó, terras, barcos, lojas, lanchas, depósitos nos bancos, servos, cartórios [...] e contas a receber (MAR, p. 395).

Como bem resumiu Guerra (2004, cf. p. 70), o poder do Coronel baseiase em quatro atributos: a posse de terras extensas, grandes rebanhos de gado,

3 Cf. W. BENJAMIN, 2006, p. 509 (citando Marx): "Não existe história da política, do direito, da ciência, etc., da arte, da religião etc."; e p. 512: "não existe uma história homogênea, por exemplo, a história da economia, nem tampouco existe uma história da literatura ou do direito". 
o fato de "ter o povo na mão" e ter à sua disposição as mulheres caboclas. $\mathrm{Na}$ verdade, cada um desses atributos desdobra-se em um complemento negativo, configurando-se assim um conjunto de abusos do poder: falsificação de escrituras, roubo de gado, exploração da mão de obra e desprezo pelos caboclos. Eis os detalhes mais significativos.

No que concerne o domínio sobre as terras, o narrador informa reportando o ponto de visto do Coronel Coutinho e de outros grandes fazendeiros - que a ilha do Marajó é para eles "um mundo à parte, privado, [que] lhes pertencia totalmente" (MAR, p. 55). A mentalidade desses latifundiários é comparada à voracidade de uma "ave de rapina”, imagem usada por Missunga para caracterizar a sua própria família (p. 272): Coronel Coutinho "devorava pequenas fazendas em Cachoeira, estreitando cada vez mais o cerco em torno das últimas e teimosas pequenas propriedades que deixavam, enfim, de lutar com o grande domínio rural” (p. 55). Um exemplo concreto é a expropriação do sitiante Tenório. Assim como o seu pai, que tinha perdido parte de suas terras por causa de dívidas, ele cai na armadilha, montada pelo comerciante Calilo, em conivência com o Coronel. Um dia, esses dois, acompanhados do Delegado e do tabelião Lafaiete, aparecem no sítio de Tenório e o obrigam a assinar um papel em que entrega sua propriedade. Ao protesto de Tenório que a dívida "não é a terça parte do que vale o sítio", o Coronel responde que não quer "bandalheira" no seu município e comenta sobre "a necessidade de educar os caboclos a obedecer leis" (p. 91-92).

Não é bem a obediência às leis que caracteriza o comportamento do próprio latifundiário, mas o seu sistemático desrespeito. Mesmo reconhecendo que o tabelião Lafaiete é "um pulha", Coutinho o convida para trabalhar a seu serviço, justamente pela "sua arte de não ter escrúpulos" e "pelas suas habilidades", especialmente a falsificação de escrituras (cf. p. 183-187). O Coronel cuida também de consolidar e perpetuar o seu poder. Ele insiste para que o seu filho obtenha o título de "bacharel" e "doutor" - pelo desejo de ver "Missunga advogando as suas questões", ou seja, "defendendo os réus amigos” (p. 47). A lei, na concepção do Coronel, é principalmente um meio para transformar crimes em atos legais.

O fato de "ter gado numeroso, à solta nos vastos campos" é, como diz o narrador, o "melhor empenho" do Coronel Coutinho (p. 55). Com as "quarenta mil reses" que ele possui, o Coronel tem em mãos uma parte considerável do abastecimento de Belém em carne. ${ }^{4}$ A importância que o gado tem para ele, expressa-se, inclusive, no seu modo de lidar com a religião. “- Quero o meu gado na graça de Deus" (p. 233) é uma de suas falas, reproduzida com jocosa ironia

Segundo Miranda Neto (2005, p. 182), havia no início do século XX um rebanho de aproximadamente 400 mil bovinos na ilha de Marajó. 
pelo narrador. O Coronel não perde ocasião para mandar "abençoar os currais", benzer o seu gado e "defumar as marcas da propriedade", ora por Santa Luzia (ibid.), ora pela pajé e feiticeira Leonardina (p. 292). Além desse zelo religioso para com o gado, ele se junta aos outros pecuaristas para pressionar o poder público. Seguindo o pai, também o seu herdeiro Missunga defende os interesses da "sua classe de fazendeiros", assinando um "memorial [...] ao governo" (p. 397).

Uma prática escusa no ambiente da pecuária é o roubo de gado. O romance apresenta lado a lado pequenos e grandes ladrões. Os pequenos são castigados, como o vendedor ambulante Elias, que recebe uma surra e perde tudo, porque "abusou, comprando carne de rês furtada" nas fazendas de Coutinho (p. 342); ou como o vaqueiro Gervásio, o qual, apenas por ser suspeito de ter roubado uma novilha, é castigado pelo Coronel com a marca do "ferro em brasa" (p. 318). Os grandes ladrões, pelo contrário, aumentam a cada dia a sua prosperidade. É o caso do comerciante Calilo, que é amigo do Coronel e "embarcava gado alheio [...], altas horas da noite" (p. 343); e também do capitão Guilherme, que é descrito por um dos vaqueiros como "turuna [isto é, um poderoso] [...] no roubo de gado e de terras" (p. 321). ${ }^{5}$ A isso acrescentam-se outros tipos de roubo por parte dos de cima. Quando o tabelião Lafaiete é acusado pelo Coronel de ter sumido com o dinheiro doado pelos devotos - "Você soca a fé dessa boa gente na entreperna de qualquer cabocla” (p. 262), ele não pode revidar às palavras do seu patrão. Mas para si (e para o leitor) ele relembra em seguida o paradeiro da parte maior daquele dinheiro, que era destinado à igreja: ele foi transformado pelo Coronel numa casa de veraneio, e o que restava foi gasto ao bel prazer pela sua jovem companheira, d. Ermelinda (p. 263).

A expressão "Coronel queria ter o povo na mão" (p. 64) tem para ele um duplo sentido: ser venerado ("povo ficava agarrado a ele como turu dentro do pau, dizia seu Felipe"; ibid.) e dominar. Seu pai, observa Missunga, "era dono daquele rio, daquela terra e daqueles homens calados e sonolentos" (p. 43). Um dos estratagemas do coronelismo é, como se sabe, o sistema de compadrio, cuja função é fazer com que os pobres se sintam protegidos pelos poderosos. Quem desempenhou esse papel no passado foi sobretudo a falecida esposa de Coutinho, d. Branca, que deixou nas recordações dos pobres a imagem de "protetora" e "madrinha do povo" (p. 54). O Coronel, por sua vez, cultiva a imagem de ser jovial e bonachão: "saía para a loja, ia passar a mão na costa de seus eleitores e fregueses, chamá-los de compadres com aquele seu à vontade tão familiar para com todos" (p. 186).

Sobre o roubo de gado na região do Arari, em época mais recente, nos anos 1970, escreve o padre Giovanni Gallo (1981, p. 73-74): "Não é o povo que furta, são uns poucos, explorados por outros poucos", destacando "o organizador do roubo, quem financia e faz o papel de receptador". 
Uma outra característica do coronelismo é cultivar a imagem pública de um "homem de fé" (CARONE, 1970, p. 252). É assim como o Coronel Coutinho, "um graúdo, um branco", consegue ser visto pelas velhas do município: "quando chegava o Divino na fazenda, carregava a Coroa [...]. Como o povo, beijava as fitas, benzia-se e ouvia, de cabeça baixa, como um pecador, a folia do Divino" (MAR, p. 232). Com a mesmo disposição o Coronel vai visitar o presépio de Natal, preparado por Guíta, filha de lenhador. Esta, porém, mais perspicaz que as velhas beatas, nos faz enxergar através da máscara: "aquele homem alto lhe parecia tão distante", "um homem rico, dono da vida e dos campos [...], falando de cima de sua riqueza e daquele orgulho que vinha por trás do ar acolhedor e bonachão" (p. 252). É precisamente essa atitude de "distância que deve haver entre pessoas de categorias diferentes" que o Coronel recomenda ao seu filho: a "distância entre o prestigiado e os prestigiadores". Como exemplo, cita o Papa: "Que seria do Papa se estivesse sempre aparecendo ao povo? [...] Que seria do Sumo Pontífice se não tivesse a guarda suíça, a pompa, o Vaticano? É uma exigência da religião" (p. 58-59.). Desta forma, é desmontada a imagem do homem de fé que se identifica com o povo. Com efeito, o Deus dos ricos é muito diferente do Deus dos pobres, como deixa claro o monólogo interior do filho do Coronel quando observa os rezadores: "Velho Deus da doceira Benedita, não és mais o meu Deus"; "Meu Deus é o da Basílica, é de um Papa que também chamam Pontífice ou Santidade [...], num trono de ouro fala difícil para o mundo" (p. 85).

"Ter o povo na mão" significa para o Coronel sobretudo: explorar a mão de obra. A dimensão histórica dessa exploração se projeta dentro do tempo presente. Ele se declara categoricamente a favor da escravidão:

O negro foi um mal no Brasil. E sua liberdade um mal maior. [...] A desgraça do Brasil foi o 13 de maio. A lavoura e a indústria pastoril não puderam mais progredir por falta de braço... Veio a vadiagem, a preguiça, a pretensão de se dar carta de abc aos pretinhos. [....] o Brasil não estava preparado para a Abolição... (MAR, p. 158).

Para defender os interesses de sua classe, o Coronel cuida de garantir a continuidade na ocupação dos cargos públicos e o controle da imprensa. "Quando o seu pai agonizava em Ponta de Pedras", informa o narrador, "já estava Coutinho escolhido para substituí-lo na Intendência" (p. 55). Da mesma forma o filho do Coronel, imediatamente após a morte deste, indica para a chefia do município um parente, o tio Guilherme (p. 395); pensando talvez para si mesmo em cargos na capital do Estado que o pai desejara que ocupasse: "secretário-geral [do P.R.F.], deputado federal, líder da câmara...” (p. 47). Quando o Coronel tenta responder a um artigo publicado na imprensa de Belém sobre as condições de trabalho nas 
fazendas e o preço da carne, o narrador realça o recurso do fazendeiro a chavões da retórica politiqueira, acusando o jornalista de "má-fé", de querer "tornar odiosa a classe dos fazendeiros", de fazer uma "pseudo defesa da população pobre" etc. (p. 157-158). No mais, as disputas na mídia são resolvidas pelo Coronel com outro tipo de argumento: ele "confessou que pagara uma vez 30 contos para sustar uma campanha absurda contra os marchantes" (p. 159).

"Qualquer pensamento para aliviar as condições do vaqueiro" - e do trabalhador rural em geral - é visto pelo Coronel "como um ato de invasão à propriedade" (p. 55). É ele em pessoa que expulsa os roceiros famintos e suas famílias da colônia agrária Felicidade depois do fracasso do projeto: “- $\mathrm{O}$ remédio é arrumar as bagagens e ir embora. Se arrumem. [...] Dêem o fora [...]" (p. 219). Quando o seu filho propõe para os vaqueiros da fazenda no Arari "uma sociedade como os pescadores", o Coronel rebate o argumento, desqualificando e criminalizando as tentativas de auto-organização dos trabalhadores:

Você sabe o que quer dizer uma colônia de pescadores no Arari? Brigas e roubalheiras. Só tem servido pra tirar dinheiro do pescador e mais nada. [...] Você deve saber que índio não tem instinto gregário ainda, vaqueiro é ainda índio, caboclo disfarçado em semicivilizado, analfabeto, manhoso e pronto para cravar a garra (MAR, p. 272).

O que caracteriza a situação nas fazendas é o domínio absoluto sobre a mão de obra, representado no romance pelo personagem do administrador escolhido pelo Coronel, Manuel Raimundo. Seu estilo de "feitor de escravos" é criticado por Missunga, que denuncia, inclusive, os furtos que ele pratica (p. 211). O Coronel rebate essas críticas, defendendo o administrador com o argumento de que ele é sua "coluna mestra" e que lhe deve "a segurança de todos os [s]eus serviços". Sabe perfeitamente que sofre alguns furtos por parte dele, mas: "nossos gênios se combinam tão bem. [...] Que desfalque de gado já me fez que me abalasse? Dou-lhe tudo quanto quiser". O essencial para o latifundiário é que seu administrador se imponha aos seus subordinados como "um general em campo" (p. 150). Manuel Raimundo, por seu lado, exibe numa conversa com Missunga a "sua responsabilidade" como administrador: " - Meu filho, [...] aqui deve haver ordem senão eles montam em nosso cangote. Seu pai sabe. São meus zelos de compadre e amigo também. Você amanhã vai saber" (p. 301 e 304).

Uma preocupação básica dos donos do poder é garantir a manutenção das estruturas de dominação. Quando o Colonel, num momento de embate com o filho, lhe lança a ameaça "te posso deserdar" (p. 381), ele o acerta no seu nervo mais sensível. "A ameaça de deserdá-lo. Seria legal? [...] E para quem a fortuna?”, são as perguntas que "sobem pela garganta" de Missunga. "Finalmente ele se 
deixa envolver pelo "único sentimento real e total", que é "o da posse universal da herança poupada e tranqüila" (cf. p. 389). Ao assumir os bens do pai e "visitar o seu domínio com o administrador", o filho herdeiro compreende rapidamente que Manuel Raimundo lhe é "indispensável" e que a ele "havia de se impor como patrão, um Coutinho, a maneira do pai com aquela cumplicidade, aquele entendimento que tanto unia os compadres". Está feito o pacto entre o novo patrão e o velho administrador, que resume a situação: "Agora é que é preciso estar de olho aberto. Temos que fazer o inventário, a contagem. É preciso estar de olho em cima. Mostrar a essa canalha que nada vai mudar" (p. 396-397).

Com todo esse poder, o Coronel exerce também o seu domínio sobre as mulheres caboclas. Diante de seus amigos em Belém ele se exibe, dizendo que sabia povoar os seus matos, cruzar o seu fidalgo sangue português com o das índias, encher a terra de povo com a marca dos Coutinhos. De que serviam as vacas e as mulheres senão para aumentar os rebanhos? (MAR, p. 55).

É com essa disposição, como relembra o remador Benedito, que o Coronel "atravessa[va] currais e porteiras", "feitorias de pesca" e "procissões nas vilas": "onde erguia a cabeça de seu alazão era para laçar nos ranchos e na beira do rio, entre as lavadeiras, a assustada moça donzela". As amantes que o Coronel distribuíra pelas fazendas do Arari, hoje “já maduronas, quase da idade [dele]”, “aparec[em] às festas de fim de ano em Cachoeira", "com os afilhados berrando na igreja [...], à espera do batismo" (p. 100-101). O sistema de compadrio é, na sociedade local - como "todo mundo sabia", inclusive Missunga - uma forma de o Coronel, "sob a capa de padrinho [...] escond[er] filhos e filhos" (p. 63). Um exemplo é Alaíde, com a qual Missunga dança numa festa e que ele leva numa noite para o igarapé; procurando defender-se das investidas dele, ela revela “ - Sou sua irmãgaua! Seu pai é meu padrinho! Sou sua irmã. Me largue" (ibid.).

Em alguns momentos, no entanto, o romance coloca alguns limites àquele "velho garanhão feliz" (cf. p. 352). Com relação à bela Orminda, que é desejada por muitos homens da ilha, e se entrega a alguns deles, o Coronel "mal podia recalcar o despeito de saber que outros homens eram amantes da filha que [ele] também desejava” (p. 263). A isso se acrescenta a frustração, comunicada pelo próprio Coronel ao filho, de ter sido abandonado pela sua amante Ermelinda em prol do seu sobrinho Nelsinho, que "veio do Rio e está metido com a cachorra" (p. 380). O que resta, no final, do domínio do Coronel sobre as mulheres e da tese de Missunga de que "o gemido das moças defloradas" tem para seu pai "o segredo de conservar-lhe a velhice e o pegadio às fazendas" (p. 274)? Essa tese é confirmada ou desmontada, conforme a perspectiva com a qual se lê a descrição do que foi o último ato do Coronel. Ele sofreu um colapso, numa casa de praia em 
Soure, sendo que "daquele subitamente cadáver, velho e gordo, que pesou sobre ela", se despojou uma "moça desgrenhada". Para o filho do Coronel, aquilo foi "um fim conveniente a um Coutinho": "o búfalo morrera por força da própria vitalidade. Aquele fim os aproximava cada vez mais, os fundia". Já o sentimento da moça, "uma pequena embrulhada num lençol", é bem diferente: ela "saiu gritando do quarto e até hoje parece transtornada" (p. 389).

A outra face do domínio do Coronel sobre as mulheres é o seu desprezo por elas e por todos os subalternos em geral. Uma observação infame, reportada por Missunga, é que ele "só distingui[a] a carne das vacas da carne das mulheres porque as vacas valiam mais no matadouro" (p. 353). As moças caboclas são vistas pelo Coronel como um perigo para o seu filho: “- Tens de voltar para Belém. [...] é preciso acabar com a história daquela cabocla" [Alaíde] (p. 99). Reiteradamente ele volta ao assunto: "Sabe que pode cair numa cilada? [...] the podem fazer uma chantagem": "Você deve partir daqui" (p. 151). O pai admite que o filho "gaste na cidade", porque isso é "razoável, humano"; "mas com essa caboclada, com esses bichos [...]?” (p. 238). Quando o Coronel, acompanhado de Lafaiete, tenta resgatar Missunga, que se retirou para um barraco com Alaíde, ela é criminalizada pelo tabelião, que a ameaça com a polícia, e demonizada pelo Coronel que a insulta: "- Sua cabocla audaciosa! Feiticeira do diabo!" (p. 380-382). Guíta, a outra mulher com quem Missunga se envolveu, sente da parte do Coronel uma atitude semelhante. Durante a já referida visita do fazendeiro ao presépio, ela "cheg[a] a convencer-se [...] que não passava de uma criada para servi-lo". E que os "cães dinamarqueses, tão bravios", dos quais o Coronel não se cansava de falar, "esses cães ele os soltaria sobre ela, se um dia fosse queixar-se do filho, ou buscar refúgio ao ser expulsa de casa" (p. 252-253).

Do desprezo dos donos do poder pelos trabalhadores braçais já vimos vários exemplos. Assim como no tempo colonial, eles são considerados objetos para serem explorados, escravos. " - Estes caboclos só a muxinga”, sentencia o Coronel, quando resolve acabar com o engenho, " - Meu pai que os conhecia e sabia como os tratava" (p. 54). Quando vê os trabalhadores abandonarem cada vez mais a vila e o município de Ponta de Pedras, em busca de melhores condições fora da ilha, o Coronel se queixa, usando uma de suas fórmulas sentimentais: " - Isso é falta de amor à terra!" O seu parente, tio Nélson, resume todo o desdém de sua classe pelos pobres com esta frase: " - Só fica a baixa categoria de gente", a gente de "ÍNFIMA CATEGORIA" (p. 68 e 71). No final, a vila é abandonada e renegada também pelo próprio Manuel Coutinho. O herdeiro do Coronel - como relata Rafaël, que cuida da igreja - declarou que "não queria mais saber de Ponta de Pedras que [...] só lhe tinha dado desgosto. Era uma joça. Deixava a vila entregue 
ao primo Guilherme que sabia tratar essa gente" (p. 455). Essa é a última palavra dos donos do poder. Mas não a do romancista, que dá a réplica, com as palavras do caboclo Rafaël:

Falei que ele [...] se lembrasse que a sua fortuna, de sua família, muito deve a Ponta de Pedras, a joça que ele dizia. Que o avô, o bisavô [...] quando veio de Portugal veio com o fundilho roto e aqui se achou. [...] Que a terra era infeliz justamente porque sempre teve homens como o pai dele e ele, tomando conta (MAR, p. 455-456).

\section{AS RELAÇÕES DE PODER - II: O LADO DOS POBRES}

O romance apresenta uma amostra das principais atividades econômicas exercidas no Marajó: as lides com o gado nas fazendas às margens do rio Arari, a pesca comercial nesse rio e no lago Arari, o trabalho dos roceiros em Paricatuba, a colheita nos açaizais de Ponta de Pedras, a extração de látex no município de Muaná e o corte da madeira nas florestas de Ponta de Pedras e de Breves. Graças à concretude das descrições, essas atividades se tornam presentes como se fossem instantâneos de um álbum de imagens: os vaqueiros trabalhando na vaquejada (MAR, p. 271), lutando para salvar os bezerros nas inundações (p. 337), embarcando o gado para os matadouros de Belém (p. 321); os pescadores cercando os peixes com as redes e jogando as tarrafas (p. 279); os homens nos roçados, cortando o mato (p. 192); as cunhatãs entregando açaí e lenha no barracão do comerciante (p. 93); a cabocla Alaíde defumando borracha na selva de Muaná (p. 439), o mestre-carpina e seus filhos cortando árvores nos arredores de Ponta de Pedras (p. 345). Acrescentam-se a isso os serviços dos empregados do Coronel como o remador Benedito (p. 35) e a doceira preta nhá Benedita. O açaí que ela amassa traz para filho do fazendeiro "o sabor do antigo tempo quando havia escravos em Ponta de Pedras", e ele se pergunta "que fim levaram [...] as netas de escravas", que trabalhavam na "batição" do algodão (p. 79). Da época da Abolição até a da ação do romance passaram-se apenas três décadas. A atmosfera do velho tempo colonial ainda pesa sobre a mão de obra, como mostram os artigos de jornais de Belém que criticam as condições de trabalho nas fazendas e as praxes dos fazendeiros e dos comerciantes de peixe (p. 155 e 281). Os próprios trabalhadores têm plena consciência da exploração, como o vaqueiro Antônio Parafuso que evita "meter a cara no serviço", pois "via muito bem como os outros caíam arrebentados e podres" (p. 313).

Um exemplo dessa exploração é o que ocorre na fazenda do capitão Guilherme. O narrador mostra o contraste entre os "barcos cheios de gado", com os quais o fazendeiro parte para Belém e, por outro lado, a situação dos vaqueiros, que ele deixa "esfalfados e famintos", depois de uma dura jornada de 
trabalho (p. 329 e 322). "- Sustento essa gente com cachaça", declara cinicamente o capitão; "é a inteligência deles. O povo quer beber enquanto trabalha" (p. 323). À falta de carne para os vaqueiros e suas famílias acrescenta-se a proibição de caça e pesca para o sustento deles e dos pescadores. "Nos lagos próximos onde há peixe”, denuncia o vaqueiro Ramiro, "o rifle dos fazendeiros está na mão do vigia atento", sendo que "os donos do rio [...] eram [...] Coronel Coutinho, capitão Guilherme [e o comerciante] Sinhuca Arregalado" (p. 338-339). O efeito visado pela proibição é obrigar os trabalhadores a comprarem comida no comerciante e se aprisionarem no sistema de dívidas:

Durante seis meses no inverno, sem peixe, sem caça, sem boa palha para a cumeeira da barraca, o pescador perdia o fôlego no balcão de Sinhuca Arregalado. Os seis meses duros de pescaria no verão não chegavam para pagar a metade da dívida (MAR, p. 280).

Os roceiros que são atraídos pela propaganda de Missunga para o projeto da plantação Felicidade, vêm com a expectativa de encontrar trabalho, comida e remédios (p. 201). Esses pobres são comparados a "feras, dotados de um faro prodigioso, [que] vinham de longe em busca das carnes" (p. 199). A voz dos famintos condensa-se numa palavra mágica:

Carne, murmuravam as crianças espantadas. Carne! disseram, com a garganta seca, os peitos doídos, a língua pesada, os homens esfalfados. Carne, cochichavam quase a medo, as mulheres grávidas, como se tudo aquilo fosse um sonho (MAR, p. 166).

O sonho desmancha-se rapidamente. Devido à falta de organização e de responsabilidade por parte de Missunga, em vez de roças cultivadas obtém-se apenas a exaustão dos trabalhadores; em vez de remédios espalham-se as doenças: febre, paludismo, verminose, alastrim e bouba (cf. p. 166, 194, 220); e em vez de poderem providenciar os seus meios de vida, os trabalhadores e suas famílias se vêem expulsos (p. 219-223). Também os que trabalham com os produtos da floresta ficam em desvantagem e com sérios prejuízos: o lenhador Amâncio e seus filhos são obrigados pelo Coronel a trabalhar também aos domingos, porque lhe "deve[m] uma conta enorme" (p. 345); as caboclas que levam açaí e lenha para o comerciante Calilo, são enroladas por ele que, além do mais - como relata o remador Benedito - espalha entre elas "doença do mundo" (p. 93); quanto a Alaíde, que teve que defumar borracha num seringal, ela não vê possibilidade de continuar e tem que "procurar serviço naqueles barracões arruinados do Muaná" (p. 439).

Devido à exploração pelos proprietários, a história cotidiana dos pobres torna-se uma "história dos sofrimentos". 6 "O mato, a gente com a sua miséria",

$6 \quad$ Este termo é de W. Benjamin, 1984, p. 188. 
resume o próprio Missunga, "tudo isso pertencia ao Coronel Coutinho, Senhor seu Pai" (p. 102). Ele tem consciência de que as muitas farras e "noite[s] de champanhe", que passou na cidade, foram "espremid[as] do suor e do sangue daqueles caboclos" (p. 43). A história dos sofrimentos é marcada por acidentes fatais de trabalho. O filho do pescador Manuel Camaleão, que "havia se atirado n’água para arrancar do fundo a tarrafa atravessada num toco ou nas pedras", morre afogado (p. 282). O lenhador Deodato "não volt[a] mais de sua comprida viagem nos rios de Breves", onde procurou ganhar a vida (p. 440). O vaqueiro Gaçaba, trabalhando no embarque dos bois, tomba na água e é devorado pelas piranhas, o que não impede o seu patrão de partir "naquela noite mesma, [...] com seus barcos cheios de gado" (p. 327-329). Também a combinação da proibição da pesca de subsistência com o onipresente sistema de dívidas faz as suas vítimas. Os pescadores na entressafra pedem fiado e acabam "deix[ando] o resto de sua vida no balcão d[o comerciante]" (p. 338). O sistema de dívidas é também, como já vimos, uma armadilha para despojar pequenos proprietários de seus terrenos. A perda da propriedade que foi seu meio de subsistência desestabiliza a vida dos desapossados: o ex-pequeno fazendeiro Guarin sobrevive como ladrão de gado (p. 284-285); o ex-sitiante Tenório torna-se ajudante de um desonesto regatão dos campos (p. 285-286), é despedido e acaba na miséria total, ajuntando-se com "uma sem ninguém", numa "palhoça à beira do rio morto" (p. 403-405).

As condições de trabalho levam também à desestruturação das famílias, como mostra a história da moça Rita. Seu pai, o vaqueiro Antônio Parafuso, depois de "quantos anos vaqueirando" numa fazenda, foi despedido com sua mulher e os quatro filhos, com a alegação de que "vaqueiro não pode ter familhão" (p. 310). A história da longa retirada deles pelos campos até a casa do tio é lembrada pela filha Rita, anos depois, numa conversa com o vaqueiro Almerindo, que também foi despedido, com o argumento de que "devia trabalhar um ano de graça para saldar a conta" e a advertência de que "está proibido amigamento nas fazendas" (p. 303). Daquela caminhada, Rita lembra especialmente o episódio do encontro com um canoeiro, que fez uma proposta aos seus pais, que sentiam os filhos como um peso: "Vocês me dão que eu levo ela pra Belém. Conheço quem precisa de uma menina assim”. A reação da mãe: “ - Está aí a menina. Por mim...” E a do pai: “ - Pode levar, o nome dela é Rita”. A transação apenas não se realizou porque a menina implorou os seus pais para não a entregarem (p. 315-316). Mas ela acabou caindo nas mãos do tio, o qual, com a ameaça de encarcerá-la, por ser filha de ladrão de gado, a vendeu como objeto sexual para o administrador. Quando Rita conta a história do seu sofrimento para Almerindo, que quer saber se "ele [o administrador] também fez contigo?" (p. 306), o vaqueiro, em vez de 
ser solidário com a sua companheira de sofrimento, a repele de modo cruel: "Te some da minha vista, ordinária" (p. 308).

O romance conta ainda os casos de várias outras mulheres que são usadas como objetos sexuais (embora às vezes elas participem desse jogo) e depois, socialmente desclassificadas. É o caso da cabocla Marta, que foi viver com seu Nélson, cuja senhora enlouqueceu, e que então procurou "uma pequena que cuidasse da casa e da louca" (p. 73). Ora, Marta deixa-se envolver pelo comerciante Calilo, que acaba por expulsá-la; desamparada, ela se arrepende e se sente, como ela própria diz, "capaz de pedir de joelhos um lugar de lavadeira pro seu Nélson" (p. 161). Alaíde, depois de ter sido deixada por Missunga, fica temporariamente na palhoça de Tenório (p. 405), depois se reergue. O destino de Guíta, a outra amante de Missunga, provavelmente teria sido semelhante, mas ela morre no acidente (p. 350). A história desses sofrimentos é resumida pelo resignado silêncio da velha Felismina, que teve um filho morto, um desaparecido, dois ladrões e a filha desonrada: "um clamor na sombra, escuro e anônimo, clamor de todas as mães de prostitutas e ladrões" (p. 140). ${ }^{7}$ Um clamor que faz eco ao grito do cego do Arapinã, lembrado por Missunga no início da história e que expressava "a voz dos homens primitivos gritando o seu medo e a sua dor" (p. 33).

Quais são as formas de resistência dos pobres diante de toda essa exploração e esses abusos? Uma forma de reação, que é imediatamente sentida pelos patrões, é a migração da mão de obra. Um desses casos é o de Francisco, filho de siá Felismina, que se recusa a continuar no regime de trabalho imposto pelos donos da ilha: "Que faço aqui?”, pergunta ele para sua mãe. "Ser eleitor do Coronel Coutinho? Apanhando açaí toda a vida? [...] É só desgosto. Só temos esta miséria" (p. 80). Francisco saiu de Marajó e alistou-se no exército em Belém, para "servir a Pátria”. O trágico, nessa opção, é que ele, que escapou aos poderosos da ilha, acaba morrendo numa revolta de rua em Belém, em que é obrigado, como militar,

\footnotetext{
A história de Orminda, a filha de Felismina, tem alguns elementos em comum com a daquelas outras mulheres, mas é diferente na medida em que ela foi vítima do rancor de pessoas do povo. Depois de sofrer o abuso sexual por parte do líder espírita Manuel Rodrigues (p. 137), ela resolveu usar livremente o seu corpo, o que provoca o ódio dos homens que ela recusa e a inveja de muitas mulheres. Em torno de Orminda, de beleza perfeita, desenvolve-se uma lenda, em que acaba predominando o elemento trágico. Em Cachoeira, conta o povo, ela foi vista "uma noite subir a torre da igreja com o próprio sacristão" e no dia seguinte, foi encontrada "a marca do corpo dela no soalho da torre" (p. 363). Diante da interpretação geral de que "Nossa Senhora marcou a sombra de Orminda no chão sagrado que a perdida profanou", Ramiro se pergunta se aquilo não foi "malvadeza das mulheres da beirada do rio", que desejavam que "aquele corpo havia de apodrecer em vida" (p. 423). O fato é que Orminda sofreu com essa perseguição e, no final, morre de "inchação" (p. 459-461). Essa história é relevante também por mostrar que o romancista, apesar de toda a sua crítica aos donos do poder, evita o maniqueísmo de idealizar o povo.
} 
a defender a causa desses mesmos donos do poder. "Meu filho morreu na revolta e os políticos bem como querem", lamenta-se a sua mãe; "meu filho com a barriga aberta na rua como qualquer desgraçado e os mandões se abraçando" (p. 81).

O “desejo de ir embora”, é nutrido também por dois jovens lenhadores, os irmãos de Guíta, tão logo que chegam na colônia Felicidade, para onde Missunga os chamou. Sua aspiração de "sair dali” para um lugar onde seja possível "lutar por um futuro" é expressa na sua relação com as ferramentas de trabalho: "Amolavam o machado como se amolassem aquele desejo de fuga. O seu desejo ficava tão agudo, tão amolado, tão cortante como os machados" (p. 180). É como se adivinhassem que em Felicidade não havia futuro nenhum. Com efeito, o desejo de ir embora concretiza-se de uma forma inesperada e não desejada: todos os trabalhadores e suas famílias são expulsos e abandonados à sua sorte.

Num dado momento, contudo, esses infelizes encontram uma forma de resposta que atinge o alvo: "Um caboclo riu alto e mulheres não reprimiam também o riso". É que "uma mulher havia arrancado a tabuleta: FELICIDADE para utilizá-la como remo". Para Missunga, o leviano idealizador do projeto, esse gesto é "pior do que vaia": "aquilo humilhava-o e o expulsava também” (p. 221). O modo como a cabocla refuncionaliza pragmaticamente a tabuleta mentirosa é um expressivo exemplo de uma "história a contrapelo", no sentido de Walter Benjamin. ${ }^{8}$ Saber remar contra a corrente de uma história infeliz é também uma das virtudes de Alaíde. Depois de abandonada por Missunga, ela consegue reorganizar a sua vida. Ela se junta com um caboclo trabalhador, Deodato, e tem com ele um filho; no entanto, ela perde os dois: o filho por doença, e o marido, por acidente. Depois de um tempo de luto, na selva de Muaná, ela resolve que "não seria [...] como aquelas mulheres, nas palhoças [...], esperando o tabaco para as resignadas [...] cachimbadas, à beira do jirau olhando a maré e a solidão" (p. 447). Decide partir de volta a Ponta de Pedras, executando no caminho os mais diversos trabalhos para sobreviver. Chegando à vila e vendo-a cada vez mais abandonada, faz planos de trabalhar numa olaria, "ou, por que não? em Belém, na fábrica” (p. 452). Esse plano se realiza, como o leitor fica sabendo ao reencontrar a personagem Alaíde num dos romances posteriores do Ciclo (em Passagem dos Inocentes, p. 211-212), que continuam a tratar da questão da migração.

Quais são as formas de resistência dos que ficam na ilha? $\mathrm{Na}$ sua rotina cotidiana, os trabalhadores tomam algumas medidas pontuais de sobrevivência contra as penúrias impostas pelos patrões. Trata-se de pequenos atos de sabotagem, como a "quebra" proposital de reses, na hora do embarque do gado. Contra o

8 Cf. a tese VII de Benjamin sobre a filosofia da história (in: M. LÖWY, 2005, p. 70), onde se trata de "escovar a história a contrapelo". 
Capitão Guilherme, que deixa seus empregados passar fome, o vaqueiro Gaçaba combina com seus companheiros: "O coirão velho nos paga. [...] Uma rês quebrada é rês sangrada". É o que de fato ocorre: o vaqueiro provoca a quebra de uma novilha. Sob as imprecações do fazendeiro cerra-se então entre os vaqueiros "uma rápida e vigilante solidariedade": "o feitor fazia vista grossa" e todos "comiam filé com pirão de leite" (p. 323). É, no romance, um dos raros momentos de alegria dos trabalhadores e de suas famílias.

A forma política da resistência, a grande revolta coletiva, não chega a se realizar. No tempo em que se passa a ação do romance, ela existe apenas em forma potencial. "Aqueles homens reunidos assim podiam revoltar-se" (p. 194), teme Missunga, quando se acumulam os trabalhadores e os problemas de organização e saúde, na colônia idealizada por ele. "Aquele povo podia se reunir, se ajuntar num só homem e abrir o rio" (p. 435), deseja por outro lado o vaqueiro Ramiro, como reação contra a medida de fechamento do rio por parte do mesmo filho de fazendeiro, que abandonou de vez as utopias sociais e perpetua o velho sistema de opressão. Ora, Ramiro sabe realisticamente, assim como o romancista, que o povo marajoara não se revoltará, por estar "desunido e com medo" (ibid.). ${ }^{9}$

Houve na região amazônica um movimento popular, mas no passado: a revolta dos cabanos. ${ }^{10}$ É uma referência histórica controversa entre os pobres e os poderosos, como mostram as já referidas observações do piloto Pedro Mala Real e do Coronel Coutinho. Esse movimento é relembrado também por siá Felismina. A morte do seu filho Francisco, numa rebelião em Belém, gera nela o "ódio" e a "revolta contra os brancos". Ela questiona o sentido das grandes palavras da retórica oficial: "Siá Felismina amaldiçoava a tal de Pátria. Chamava os caboclos e os caboclos iam morrer em defesa duns homens que desonravam a pátria” (p. 81). Ela deseja "uma nova cabanagem", "uma grande cabanagem no mundo", "para acabar com muito branco" (p. 82 e 367). Essa memória da grande revolta política, por vários pobres, mesmo não levando a nenhuma ação concreta, não deixa de ser uma parte da construção de sua identidade e uma forma de resistência.

Uma vez que faltam, por parte dos oprimidos, ações de resistência mais organizadas, o romance Marajó pode parecer uma crônica de suas derrotas. Contudo, os próprios registros desses reveses - como o das "últimas e teimosas

\footnotetext{
9 A luta dos trabalhadores, naquele início do século XX, realizou-se numa outra parte do Brasil, no Rio Grande de Sul, como descreve Dalcídio Jurandir em Linha do Parque (1959), o único de seus romances que não faz parte do Ciclo do Extremo Norte.

10 Sobre a Cabanagem, ver Pasquale Di Paolo (1990).
} 
pequenas propriedades que deixavam, enfim, de lutar com o grande domínio rural" (p. 55) - não deixam de ser também testemunhos de lutas. ${ }^{11}$ Certos dados da história presente real nos fazem reconsiderar e reavaliar aqueles momentos de lutas aparentemente perdidas. Se tivesse havido apenas derrotas dos oprimidos, daquele tempo de 1915-1920 para cá, como explicar a existência, neste início do século XXI, de uma expressiva organização política dos quilombolas na ilha de Marajó em defesa de seus territórios? ${ }^{12} \mathrm{O}$ que atesta o status dos pobres como sujeitos da história, nessa resistência, é sobretudo a conquista de uma fala autônoma. A inclusão, por parte do romancista, de expressivas falas próprias dos caboclos como a da mulher que arrancou a tabuleta FELICIDADE, para utilizá-la como remo - foi uma iniciativa literária pioneira, que é amplificada pelos movimentos políticos no presente.

No mais, a principal forma de resistência descrita no romance são as chulas ou canções de protesto do vaqueiro Ramiro. A chula, como esclarece Marcus Leite (2004, p. 116) com base nas descrições do viajante inglês Alfred R. Wallace, é um gênero de canção de protesto que se situa na tradição das músicas dos escravos:

Seu instrumento é uma espécie de viola primitiva, da qual tiram apenas três ou quatro notas, repetindo-as horas a fio [...]. Em cima dessa pobre melodia, improvisam uma letra, geralmente com os acontecimentos daquele dia. Os feitos dos brancos são os temas mais freqüentes dessas canções (WALLACE, 1853; ed. 1979, p. 68).

O vaqueiro-poeta Ramiro, que "não tinha emprego certo nas fazendas" e trabalhava somente "quando a necessidade era muita", é livre, assim como Orminda, que passa algum tempo com ele, é uma mulher livre. ${ }^{13} \mathrm{O}$ amor aguça a sensibilidade de Ramiro, inclusive quando fala da memória coletiva: do "grito dos vaqueiros mortos", da proibição das caçadas nos lagos das fazendas, da luta para sobreviver, e também das festas, como a de São Sebastião em Cachoeira (p. 428). "As chulas de Ramiro", resume o narrador, "falavam dos vaqueiros", da "pessimidade" e dos "podres dos brancos", e "davam vida" (p. 319). Há uma forte empatia entre o vaqueiro-poeta e o seu meio social: "as chulas corriam os campos, batiam bem fundo no coração do povo” (p. 275). Com suas canções de

11 Isso vale igualmente para o romance seguinte de Dalcídio Jurandir, Trếs casas e um rio, onde ele relata um caso de firme resistência de um sitiante, Manuel Bolacha, contra as investidas do latifundiário Edgar Menezes, que acaba lhe tomando suas terras. Mesmo que este e mais alguns casos narrados terminem com a derrota dos pobres, houve por parte deles resistência e luta.

12 Cf. os documentos apresentados e comentados por Rosa Acevedo Marin (2005, 2006b e 2008).

13 Uma das formas de resistência pela qual os poderosos se sentem particularmente atingidos é o comportamento da bela Orminda: ela se entrega a vários homens de sua condição social, mas se nega ao Coronel, a Missunga e a Lafaiete. Quando este pretende seduzi-la, ele é ridicularizado (MAR, p. 119-120). 
protesto, Ramiro faz questão de distanciar-se de ficções folclóricas inócuas como a história de Maria do Pau e do príncipe, narrada pela cabocla nhá Diniquinha como uma espécie de consolo para os pescadores que se perguntam "onde achar o peixe?" (p. 432-433). Ele quer "outras histórias", como a do rio Abaí, fechado para os pescadores e que "ninguém contava. Nhá Diniquinha não sabia ou tinha medo de contar". Ramiro imagina que Orminda certamente lhe pediria nessa situação de fazer uma canção de cunho político e social: “ - faz chula deste teu rio Abaí e lasca no seu Manuel Raimundo" (p. 434). Nessa altura, o vaqueiro-poeta já sofreu as consequências do seu engajamento: Ramiro é expulso de todas as fazendas onde trabalha, pois os donos têm "medo da [sua] língua e da música": "seus instrumentos lhe davam aquela liberdade, aquela cadencia, aquela franqueza que os brancos temiam" (p. 319).

As chulas ou canções de protesto do vaqueiro Ramiro contêm, inclusive, alguns traços de autorretrato do crítico social que foi Dalcídio Jurandir, alguns princípios que caracterizam a sua postura diante da relação entre a literatura e a política. Dentre eles destacam-se o distanciamento das formas corriqueiras de consolo e o próprio fato de dar voz aos pobres.

A forma de consolo mais banal à qual recorrem os oprimidos e humilhados, é a cachaça. Até o cantador de chulas, Ramiro, chega a entregar-se a ela numa ocasião em que dois vaqueiros o convidam para beber. Das coisas que "aquelas três bocas buscavam no fundo do garrafão" constam desejos como os "[rios] Abaís abertos a todos os pescadores", "quartos de carne sabrecando em grossos espetos na fogueira", "misteriosas felicidades", "farinha muita farinha" e, como desforra: a visão do administrador "Manuel Raimundo num tacho de fogo e o Diabo com uma colher de ferro mexendo o caldeirão" (p. 436).

Outro tipo de consolo são as já referidas histórias feéricas, tais como as conta nhá Diniquinha, como também as consultas aos pajés: "volvia-se para o pajé aquela humanidade marajoara com todos os cheiros suados de seu trabalho" (p. 414). Aqui é preciso, no entanto, fazer a ressalva de que os que procuram o pajé não são apenas os pobres, mas os "desenganados dos médicos", em geral, entre eles também "brancos fazendeiros", "advogados", um "espancador de caboclos" e o próprio administrador Manuel Raimundo, que sente "mistério e milagre" na voz do pajé mestre Jesuíno (p. 414 e 416). Ainda com relação à pajelança, vale destacar o retrato que o romancista fornece da pajé nhá Leonardina. Quando ela entra em cena pela primeira vez, é apresentada como uma figura que dispõe de uma "misteriosa força" e de um notável poder: não apenas para "fechar o corpo de Orminda contra a desgraça" (p. 190), mas também para proteger o gado do Coronel Coutinho, que manifesta "temor diante da fama de sua amiga [e] lhe trazia 
presentes da cidade", ou ainda para fazer "matar todo o gado do Major Milico", em resposta a uma ameaça que ele lhe fez (p. 290, 292, 298). Ora, na cena em que ela reaparece, o romancista desmonta todo o encantamento: "A pajé perdia o poder da invocação", "Onde o poder das palavras? Quem cortou a língua da feiticeira que os donos do mundo temiam?” (p. 335). Nhá Leonardina murmura apenas mecanicamente a sua toada e fica a brincar com bonecas como uma criança. Com essa desconstrução, o romancista desmonta também os consolos dos que se apóiam na magia e na feitiçaria.

Restam os consolos da religião, que são mais complexos. "A folia consolava o mundo da fome, da peste e das lágrimas" (p. 228), comenta criticamente o narrador num capítulo-chave, onde descreve o fracasso da colônia Felicidade e em seguida, com precisão antropológica, as festas religiosas e o culto dos santos, da perspectiva de um folião. Na vila de Ponta de Pedras há várias facções religiosas, com uma forte rivalidade entre elas. O responsável pela igreja, tio Rafaël, é o líder do principal grupo religioso. Ao observar com Missunga um grupo desses rezadores, o narrador anota: "Vinte séculos de fé amassados de superstição e humildade saindo com um travo na voz dos rezadores" (p. 82). Ouvindo a ladainha, o filho do Coronel sente-se denunciado. Ele tenta, mentalmente, interceptar esses "sofrimentos, humildes demais para subirem ao céu", com uma espécie de prece às avessas: "Nossa Senhora não ouvirás meus irmãos sem nome nem as prostituídas pelo meu pai e pelos meus tios, santa do Agnelo, o bêbado, do Marcelino, o ladrão e do Ciloca, o leproso" (p. 85). Através do personagem Missunga, a fé e o culto dos santos são mostrados como coisas construídas. Isso fica muito claro num dos últimos episódios, a noite de insônia em que Missunga se sente rodeado por "todos os fantasmas" (p. 418). Os santos no oratório lhe aparecem, então, "como se tivessem voltado à primitiva condição da madeira e da massa informe em que foram moldados", ou seja, eles "se desp[em] de toda a santidade" (p. 419).

$\mathrm{Na}$ descrição da festa de Nossa Senhora da Conceição, o narrador, que acompanha os foliões ao lado de Tenório, traz à tona uma série de aspectos profanos, desde a hierarquia dos grupos até os interesses materiais que estão em jogo. Enquanto os grupos mais prestigiados são os do Divino e de Nossa Senhora, e o de São Sebastião ocupa uma posição intermediária, o de Santo Ivo é o mais humilde. É a este santo que Tenório “entregava a sua miséria” (p. 216). O exdirigente do grupo, Manuel Rodrigues, que depois se converte ao espiritismo, é visto com desconfiança pelo líder Rafaël. "Aquelas vozes” dos foliões de Santo Ivo "subiam [...] dos peitos como de poços fundos e de fundas feridas, num desespero e numa agonia que só os foliões, os desgraçados, os pobres podiam sentir" (p. 228-229). A “tiração das esmolas pelo Arari, Marajó-açu e Camará, quando 
se faziam os grandes embarques de gado e começava a safra de peixe nos lagos" (p. 127), tinha um sentido pragmático. Para os foliões como Tenório, "Santo Ivo [...] dava religião em troca de cachaça e mel puxa-puxa" (p. 230). Já para o chefe da comissão, Manuel Rodrigues, os donativos eram o meio com que "ganhava sua vida" (p. 127-128). Seu retrato ficaria incompleto se não se mencionasse que foi parar no xadrez, por ter abusado sexualmente de várias moças, entre elas Orminda, que lhe serviam de "médium" nas sessões espíritas (p. 137 e 145), No final, como relata Rafaël, Manuel Rodrigues "montou a banca de bicho na vila e rapa todo o miúdo dessa gente...” (p. 456). Eis um caso de como a procura de consolo religioso contra a exploração acaba sendo aproveitada por alguém que sabe tirar partido da fé do povo no milagre, e a reverte num novo tipo de exploração.

Como vimos várias vezes, ao longo desta descrição da condição dos pobres, a forma de solidariedade de Dalcídio Jurandir com eles não consiste em idealizá-los e, sim, em lhes dar voz e em mostrar suas aspirações e sonhos. Veja-se, por exemplo, o detalhe aparentemente insignificante de que Alaíde "principiou a conhecer as letras" com uma professora para a qual ficou cozinhando durante algum tempo (p. 448). Ou o momento em que ela, no final, volta para Ponta de Pedras e ouve o canto dos fiéis na igreja. Alaíde pensa, então, em Guíta e Orminda, imaginando que elas poderiam estar ali cantando também, e que sua história poderia ter sido diferente:

por que elas, tão moças, sofreram tanto, por que não puderam cantar as novenas, brincar de jogo de bola, remar pelos estirões, namorar muitos rapazes, dançar com rosas no cabelo, sem que nenhuma delas se perdesse? (MAR, p. 452).

Esse desejo faz eco a um pensamento da mãe de Orminda que lamenta que sua filha, que "cantava no coro da igreja" está "agora no mundo". Ela sabe que "Orminda [...], se estudasse dava uma professora" (p. 142-143). Quando lembramos que os filhos do pescador Manuel Camaleão o qual, por causa de uma prejudicial crendice, "não mandava ensinar os filhos a assinar o nome porque pescador que aprende a ler fica panema, sem sorte nenhuma para a pesca" (p. 283), podemos completar o desejo da mãe, imaginando que para esses alunos Orminda seria uma excelente professora. Com fragmentos desse tipo, que falam da percepção do mundo pelos caboclos e de seus desejos, o autor de Marajó faz o leitor pensar que a história marajoara certamente seria outra se a sua narração e sua escrita ficassem por conta dos caboclos. 


\section{PROCEDIMENTOS DE MEDIAÇÃO}

Como se realiza no romance,em termos de construção literária, a mediação entre ricos e pobres, no nível da ação narrada, e paralelamente, entre o mundo dos caboclos ali representado e o dos leitores cultos? Um estudo que nos pode fornecer parâmetros para esta investigação sobre a obra Marajó, é o panorama de artigos organizado por Roberto Schwarz na antologia Os Pobres na Literatura Brasileira (1983). Ao mesmo tempo em que nos inteiramos do tratamento desse tema em 35 escritores, desde o século XVIII até o final do século XX, acompanhamos ali também o trabalho de 35 críticos brasileiros. Uma dessas vozes é a de Lígia Chiappini M. Leite, que é também autora de um estudo no qual ela ampliou e aprofundou o seu ensaio de 1983. Nessa publicação mais recente, "Velha praga? Regionalismo literário brasileiro", de 1994, ela faz uma revisão crítica dos preconceitos contra o regionalismo. Essa corrente literária - como se pode verificar pela recepção da obra de Dalcídio Jurandir - é considerada por vários críticos como sinônimo de qualidade literária inferior, à qual se opõem as obras de nível "universal". ${ }^{14} \mathrm{Com}$ tal atitude, no entanto, comete-se uma injustiça em relação ao romance regionalista brasileiro, uma vez que esse gênero, de cunho semificcional e semidocumental, assumiu uma série de tarefas que são próprias das ciências sociais.

Para um tal diálogo entre a literatura e as ciências sociais, a referida antologia de Roberto Schwarz oferece um rico material. Com base nos procedimentos postos em obra pelos escritores e, paralelamente, nos conceitos utilizados pelos críticos para descrevê-los - incluindo-se as posturas e as ideologias subjacentes aos trabalhos desses dois grupos de profissionais - pode se esboçar uma tipologia das estratégias de mediação literária. O panorama que daí resulta estende-se desde a literatura documental até a crítica, a sátira e a denúncia; da literatura e da música populares até os sentimentos de compaixão, culpa e rebeldia por parte dos autores burgueses; de idealizações sentimentais e folclóricas até o engajamento populista, a propaganda e a luta de classes; desde a autorreflexão dos escritores sobre o seu lugar social e os procedimentos de dar aos pobres uma voz na literatura, até os (raros) casos em que pessoas das camadas sociais mais baixas se tornaram autores ou autoras. Para nós coloca-se aqui a tarefa de situar nesse panorama geral da literatura brasileira a obra de Dalcídio Jurandir e de avaliar qual é a sua contribuição específica. Isso é tanto mais necessário quanto, na referida antologia, a literatura sobre a Amazônia se manifesta em apenas dez linhas (um comentário a Euclides

14 Sobre a recepção da obra de D. Jurandir, inclusive a discussão do "regional" e do "universal", veja-se G. Pressler (2004) e (2006). 
da Cunha) e em três versos (de Augusto dos Anjos), sendo que dos escritores da Amazônia nenhum está presente. Ou seja, a literatura da região que ocupa cerca de 40 por cento da superfície do país, foi esquecida pela crítica brasileira.

Em comparação com Euclides da Cunha, que escreveu sobretudo em nome dos sertanejos e dos caboclos, concedendo-lhes a palavra apenas em alguns momentos, Dalcídio Jurandir constrói a sua obra essencialmente como um espaço para as pessoas do povo se expressarem. Os seus primeiros três romances, que todos têm como cenário a ilha de Marajó, contêm uma detalhada reflexão sobre o lugar social do escritor e são experimentos concretos com diversas estratégias de mediação, o que faz com que eles constituam um enriquecimento significativo para o conjunto da literatura brasileira.

Na sua obra de estréia Chove nos campos de Cachoeira (1941), em que a sociedade de uma vila do interior da Amazônia é apresentada a partir da perspectiva microhistórica de uma família, o que será o caso também na maioria dos romances seguintes, o narrador acompanha ora a perspectiva do menino Alfredo, de uns dez anos de idade, ora a do seu irmão Eutanázio, de quase quarenta anos e que adoeceu de sífilis. O componente erótico desempenha um papel importante na opção do autor por esta figura de sondagem na sociedade local. Com a narração da paixão de Eutanázio pela adolescente Irene e as suas visitas na casa dela, mais uma família é incorporada à apresentação; juntamente com as falas de diversos tipos de informantes que Eutanázio encontra em suas caminhadas pela vila, resulta daí um tableau social amplo e representativo. Por outro lado, também o personagem do adolescente Alfredo oferece várias vantagens como figura de mediação, como se percebe logo a partir do capítulo inicial. O fato de ele ser filho de um funcionário público branco, o Major Alberto, e de uma empregada negra, d. Amélia, que o Major, depois de ter ficado viúvo, escolheu como companheira, faz de Alfredo um go-between entre as classes, numa sociedade marcada pelo antagonismo entre ricos e pobres e pelo racismo.

No seu segundo romance, Marajó (1947), Dalcídio Jurandir, escolheu como figura de mediação o filho rebelde de um fazendeiro. Quais são as vantagens e as desvantagens dessa opção? Podemos supor que o leitor tem inicialmente três bons motivos para identificar-se com esse protagonista: 1) o fato de se tratar de um personagem da classe e da cultura dominantes e que pertence assim como o leitor ao universo da norma culta; 2) a característica da rebeldia, que oferece uma identificação para aqueles leitores que querem olhar além do horizonte de sua própria classe ou são ideologicamente dissidentes; 3) a disposição para o diálogo com os pobres, para o qual o nome Missunga é simbólico. Esse nome designa, como esclarece V. SALLES (1996, p. 67) um "menino branco com linguagem de 
negro". Através de sua ama de leite negra e do contato com outras domésticas que trabalham em sua casa - sendo que com algumas delas o seu pai gerou filhos -, Missunga tem desde a infância uma forte ligação afetiva com as mulheres caboclas. Para a construção do personagem mediador é particularmente reveladora esta passagem:

É verdade, aquela velha negra foi amante de seu pai, seus filhos meus irmãos (MAR, p. 79).

Através da mudança do pronome possessivo na mesma frase cria-se uma relação muito estreita entre o narrador, que fala na terceira pessoa ("de seu pai") e o monólogo interior do protagonista Missunga, na primeira pessoa ("meus irmãos"). A familiaridade de Missunga com o mundo dos empregados e a sensualidade de suas memórias de infância o predispõem para ser uma figura que possa introduzir o leitor à cultura cotidiana do povo, sendo que o narrador acompanha a percepção e o pensamento dele, ora de perto, ora se distanciando.

Os tableaux etnográficos, nesse romance, nascem em boa parte do interesse de Missunga - que voltou da cidade, onde se cansou dos estudos e das farras - pelo mundo dos caboclos. Enquanto "ficção etnográfica" (a denominação é de Zélia Amador DE DEUS, 2001, p. 94), Marajó é estruturado em torno de dois eixos paralelos: a história de Missunga e um correlato roteiro de pesquisa antropológica, traçado em boa parte por ele. Assim o leitor vai conhecendo a topografia social da ilha, em recortes representativos tomados na vila de Ponta de Pedras, e nas fazendas à beira do rio Arari. Como observador participante, Missunga escolhe determinados pontos de encontro, onde descreve as pessoas e entra em contato com o povo. Pontos como a loja do seu pai, junto ao trapiche, onde os homens "vinham com a garrafinha de querosene, pediam sal, uma quarta de café em grão, os dois dedos de tabaco" (p. 67), ou, do outro lado do rio, em Paricatuba, a venda do comerciante Calilo, onde "as cunhatãs [...] iam comprar cheiro e tabaco a troco de açaí e lenha" (p. 93); ou a porta da igreja, onde se juntam os rezadores, que são detalhadamente descritos enquanto rezam a ladainha com tio Rafaël (p. 81-86). Em outros momentos, Missunga visita as pessoas em suas casas e conversa com elas: seu Felipe e d. Januária, no sítio deles em Paricatuba (p. 64-66); tio Nelson e d. Marta (p. 71-75); o lenhador mestre Amâncio, no Campinho, e sua filha Guíta (p. 102-110); Alaíde, na barraca onde ela mora com a tia (p. 121-125; e novamente a casa de seu Felipe, onde assiste à sessão espírita de Manuel Rodrigues (p. 134137). Na viagem com o pai à região do rio Arari, Missunga "corr[e] os campos, as fazendas, dias e dias nas vaqueiradas, [...] ferras, [...] rodeios, embarques de gado nas caiçaras" (p. 272); ele "vai com os vaqueiros para a caça do búfalo nos campos 
selvagens" (p. 273), assiste "a tarrafeação, a lanceação" e "a salga do peixe nas feitorias" (p. 280 e 282); ouve as histórias de vaqueiros e pescadores (p. 279); e passa a noite dançando e bebendo no meio dos caboclos (p. 301). A reação deles atesta o sucesso de Missunga como mediador:

Os vaqueiros gostavam dele: um branco muito dado. Não se metia a besta, sabia brincar, selar e montar um cavalo, beber com toda gente, e aprendia a atirar nos patos voando, dava gorjetas, pagava festas, comia em cima da porteira a carne frita na própria gordura que as mulheres the traziam (MAR, p. 274).

Essa aceitação por parte dos vaqueiros contrasta com o "alheamento" dos caboclos que Missunga experimentou inicialmente em Ponta de Pedras, quando "tentou pedir a um deles qualquer coisa, falar-lhes para que uma intimidade os unisse, [...] desejos de ir com eles armar camboas para peixe" (p. 67). A diferença entre essas duas atitudes pode ser o sinal de um entrosamento progressivo, mas também um indício da distância e da desconfiança que os caboclos fazem questão de manter em relação ao filho de um dos donos do poder.

A questão da rebeldia do filho contra o seu pai, o poderoso Coronel Coutinho, é complexa. Ela se manifesta tanto no seu experimento de uma reforma social quanto em suas relações com as caboclas. Ambos contêm motivos para o leitor continuar a ver Missunga com simpatia: o seu engajamento social é, em princípio, uma causa nobre, e um romance de amor e de sexo é um contraponto interessante para os estudos antropológicos não ficarem demasiadamente impessoais e abstratos. "Por que viera da cidade para aquele torpor?" (p. 36), pergunta-se Missunga, tentando compreender o que "o empurrav[a] para aqueles matos" da ilha de Marajó. Além do "desengano nos estudos" e do "mal da fartura" (p. 57), no duplo sentido de "abundância" e "fastio", é a atração que ele sente pelas moças caboclas, bem diferentes daquela moça da cidade com quem namorou por último e que "o queria prender, entregar-se, engatar na sua herança!" (ibid.). Alaíde, ao contrário, era "mansa como a terra" e "se abandonava [...] com uma animalidade tão inocente [...] que havia naquilo a sensação quase do incesto" (p. 110). Missunga resolve também retomar o contato com um outra cabocla, Guíta, com quem brincava na infância, que lhe dera (provavelmente) o apelido de "Missunga" e que agora é uma moça feita, suscitando nele o desejo de "ensiná[-la] a amar, a fazer de seu corpo uma perfeita máquina de prazer" (p. 110). E, como se não bastasse, Missunga, ao passar pela barraca da bela Orminda, imagina que esta também poderia tornar-se "sua amante, amanhã, quem sabe?" (p. 110).

Onde está, então, a diferença do comportamento de Missunga em comparação com aqueles outros jovens fazendeiros que ele chega a invejar, porque 
"tinham [...] as caboclas que queriam" (p. 268) e praticavam nas suas fazendas "as brutas farras com caboclas" (p. 43); e o que o diferencia do seu pai e do seu tio, esses "velhos garanhões felizes", que "multiplicavam aquele sujo e desgraçado rebanho em que se viu apanhado [...] entre Guíta, Alaíde, e Orminda" (p. 352 353)? Quando o próprio Missunga imagina que "bem podia ter ele o direito de ser o pai da futura meninada do Marajó-açu. Seria mais tarde o patriarca da vila, [...] fazendo raça com as cunhatãs, os afilhados lhe tomando a bênção"; e quando se vê no futuro papel do "padrinho abençoando o povo" (p. 77), ele não reproduz exatamente a mentalidade do Coronel Coutinho? Onde está a rebeldia? O ponto de conflito de Missunga com o seu pai não é o seu interesse erótico pelas caboclas, mas o fato de ele ligar-se a elas também afetivamente: "Cansei-me de procurar uma noiva em nosso meio", declara ele ao pai (embora "sem convicção", como observa o narrador), "quero agora uma mulher simples ao meu lado. [...] uma companheira" (p. 266). É isso que preocupa o Coronel, pois uma relação baseada em sentimentos poderia colocar em perigo a situação existente de hierarquia social e de propriedade.

O núcleo da rebeldia é o projeto da plantação Felicidade, que simboliza uma expectativa de ruptura com as velhas estruturas coloniais e de implantação dos ideais da modernização. Ora, há em Missunga uma mistura dessa sua rebeldia social com suas aventuras erótico-sentimentais. Isso influencia também o tipo e grau de uma possível identificação do leitor com o protagonista, da qual o episódio em questão representa o auge e a queda. Um prenúncio é a cena em que o filho do Coronel atira na lama o peixe podre que o comerciante Calilo queria vender para as caboclas. O monólogo interior de Missunga - "gostaria que Alaíde tivesse assistido à cena, e Guíta, e os amigos de Belém que o aplaudiriam” (p. 98) - faz com que o leitor se pergunte: trata-se de uma autêntica defesa dos pobres ou apenas de um gesto teatral, para satisfazer a própria vaidade? Esta pergunta coloca-se mais fortemente no caso da colônia agrária Felicidade, idealizada por Missunga. O projeto é vago desde o início, oscilando entre a dimensão social de providenciar "a felicidade [...] de toda gente" (p. 102) e o idílio particular de fazer "um pomar para Alaíde" (p. 150). Concomitantemente com a chamada de trabalhadores para a plantação, Missunga cultiva o seu duplo relacionamento erótico com Alaíde e com Guíta. Quando, na "caça à Guíta”, Missunga registra “[n]o olhar dela [...] uma infinita simpatia, [...] talvez pelo que ele fazia pelos pobres em Felicidade" (p. 169), fica claro que a ação social é para ele também um meio para a conquista erótica. Durante a execução do projeto - quando as dificuldades se avolumam de forma inquietante - o idealizador do projeto refugia-se no mundo dos prazeres sexuais. A intervenção final do pai, que Missunga queria desafiar com o seu projeto social 
e que acaba expulsando os trabalhadores, é sentida pelo filho como um "alívio": "Era assim o caminho aberto para se entreter, unicamente, com Guíta" (p. 219220). Com isso, fica claro que, para Missunga, a experiência social de Felicidade, que envolveu dezenas de trabalhadores e suas famílias, estava subordinada às suas aventuras eróticas.

Considerando-se essas premissas da colônia Felicidade, fica fácil entender porque fracassou. O sonho inicial de Missunga foi este:

Estender minhas plantações. [...] Adiante o armazém, casas de colonos, o arrozal nas baixas. Algodoais branquejando na luz da manhã. A trepidação dos tratores. Caminhão buzinando na estrada e a felicidade entrando pelos olhos de toda gente (MAR, p. 101-102).

À primeira vista, o projeto pareceu corresponder às necessidades do povo: "agora vai haver trabalho", "carne" e "muita farinha!" (p. 165-166 e 171); os caboclos chegam a "fala[r] na "bondade do moço" (p. 172). Na execução do projeto, no entanto, revela-se a falta de objetividade (p. 194) e de planejamento consistente: o afluxo dos trabalhadores e de suas famílias é descontrolado e configura uma "invasão" (p. 200); faltam ferramentas e sementes (p. 165 e 171), o abastecimento de comida é improvisado (p. 207), e não há um serviço de saúde para dar conta das doenças e dos acidentes. No meio de toda essa confusão, surge um desentendimento entre Missunga e Alaíde quanto ao posicionamento social dela. $\mathrm{O}$ fato de ela engajar-se integralmente pela causa do seu povo, "ajuda[ndo] as mulheres na cozinha, i[ndo] com elas carregar lenha, leva[ando] comida aos trabalhadores", provoca impaciência em Missunga, que explica a Alaíde que "o lugar dela não era no meio deles, mas na barraca, ajudando-o" (p. 200). Cria-se uma situação em que o filho do Coronel reconhece que "agira afobadamente" e que "faltava sentido" em seu projeto (p. 201). Ele é dominado então pelo "medo do povo" (p. 200) e teme que "aqueles homens [...] podiam revoltar-se, não saberia como subjugá-los" (p. 194). Não há nenhum diálogo efetivo entre Missunga e os trabalhadores. ${ }^{15}$ A mediação social, que ficou por conta da cabocla Alaíde, é precária, pois ela não tem o apoio dele. No triste final, quando as mulheres dos trabalhadores se despedem - “- Alaíde, até a volta, um dia nós se vemos” (p. 222) -, todos sabem que em breve ela seria "mandada embora também tão coisa nenhuma como o povo que partia" (p. 222). Quanto às demais melhorias, sociais, técnicas e econômicas,

15 Uma cena que evidencia essa falta de diálogo, como já foi bem observado por M. Furtado (2007, p. 105) é a seguinte: “- E os instrumentos? / - Que instrumentos? Os de música? Então vocês antes de trabalhar já querem dança? / Os homens sorriram, com um ar de desânimo e cansaço, os rostos escuros. / - Os machado. As enxada. As foice. / - Ah! Vocês não trouxeram? Eu pensava..." (MAR, p. 165). 
que são ainda propostas ou sonhadas por Missunga - uma sociedade de vaqueiros (p. 272), a "drenagem dos campos, para evitar as enchentes" (p. 268), uma “fábrica de conserva de peixe", um "entreposto moderno, maquinismos importados dos Estados Unidos” (p. 282) -, ele já perdeu toda a credibilidade. Parece que com o episódio de Felicidade, o romancista alude criticamente a todo um conjunto de projetos de modernização que já foram formulados para Marajó e que fracassaram.

A partir do malogro do projeto Felicidade (capítulo 23) e definitivamente depois de ter entrado na posse da herança (capítulo 47), Missunga procede à liquidação dos seus sentimentos para com suas amantes caboclas. Primeiro com Alaíde, que está esperando um filho dele. Missunga "concluiu, com sórdida amargura, que nenhuma curiosidade tinha pelo nascimento daquela criança" (p. 225); depois do aborto, ele sente "nenhuma piedade por Alaíde!” (p. 241-242). Guíta, então, que ele também engravidou, lhe parece "talvez [...] mesmo a solução menos ruim" (p. 339). Para consolar-se da perda dela, Missunga procura novamente a companhia de Alaíde, que percebe que está sendo usada. Eles acabam se agredindo, e o seu "romance" revela-se finalmente como uma ilusão. No momento em que Missunga se torna herdeiro dos bens do pai, ele "romp[e] de uma vez para sempre com as emoções" (p. 389). Nessa hora está cioso também de sua imagem social: "Não podia aparecer com [Alaíde] na vila [...], não queria ser visto ao lado da cabocla" (p. 390). Alaíde, que sabe que o sentimento se acabou, responde à altura: "Não pense que eu queria que você ficasse. Por isto vá logo. [...] Eu sigo a minha sorte" (p. 392-393). Desfeito o romance entre o filho do fazendeiro e a cabocla pobre, cada um dos dois retorna para o seu meio social.

A tarefa da mediação entre os antagonismos sociais fica agora inteiramente por conta do narrador. Embora o romancista tenha utilizado ao longo da obra também a perspectiva de vários personagens caboclos, ele sabe que com a saída de Missunga perdeu-se a perspectiva de alguém vindo de fora e com uma educação letrada, o que é importante como apoio para o leitor que não é familiar com aquele universo. Contudo, nesta altura, o romance já chegou quase ao fim, e é coerente com o projeto literário geral de Dalcídio Jurandir que nas últimas cenas os caboclos retomem a palavra.

Neste contexto pode ser instrutivo esboçar uma comparação com o protagonista-narrador que Guimarães Rosa criou em seu romance Grande Sertão: Veredas (1956) com a figura de Riobaldo. A partir da ótica dos experimentos literários de Dalcídio Jurandir, e de uma concepção da literatura brasileira como um projeto coletivo, o personagem de Guimarães Rosa parece ser o resultado de um processo de aprendizagem. Assim como Missunga, também Riobaldo é filho de um fazendeiro. No entanto, diferentemente daquele "branco", ele é "de escuro nascimento", pois a sua mãe é, como no caso de Alfredo, uma mulher pobre 
do povo. Nas suas relações amorosas, Riobaldo, diferentemente de Missunga, sabe distinguir muito bem entre suas aventuras eróticas com uma moça do povo (Nhorinhá) e seu noivado com a filha de um fazendeiro (Otacília) - sendo que para o seu amor por Diadorim não existe nenhum paralelo na obra de Dalcídio Jurandir. O sentimento de superioridade e de culpa de Riobaldo em relação aos pobres sertanejos encontra sua expressão na opção do autor por um protagonista que fez um pacto com "o pai da mentira" e o qual, dessa forma, se torna um narrador não confiável. Com tudo isso, Guimarães Rosa reuniu, por assim dizer, vários elementos que estão esparsos na obra de Dalcídio Jurandir e os sintetizou na construção de sua figura de mediador. ${ }^{16}$

Como avaliar, em termos de conclusão, a opção do autor de Marajó por Missunga como figura de mediação: trata-se de um experimento fracassado ou bem-sucedido? No nível da ação do romance, pode-se falar em malogro, uma vez que o comportamento sentimental do protagonista e as suas ideias românticas de reformas sociais se revelaram como autoenganos. Por outro lado, a trajetória de um personagem que inicialmente é simpático, e com o qual o leitor pode se identificar, e a sua transformação numa pessoa egoísta e antipática, não deixa de ser uma construção narrativa bem-sucedida, na medida em que pode fazer ver ao leitor próximo das camadas dominantes os (autoenganos de um namoro (seu) com projetos de modernização social, nos quais os caboclos, ou seja, as pessoas das camadas de baixo continuam sendo meros objetos, e não ascendem à categoria de sujeitos da história. Em seu terceiro romance, Três casas e um rio (1958), Dalcídio Jurandir volta a apresentar o personagem de um filho de fazendeiro que se entusiasma por reformas sociais, Edmundo Menezes, mas desde o início este é apresentado de modo crítico e distanciado. Como figura de mediação social, o autor opta agora definitivamente pelo personagem mais aberto de Alfredo, que apareceu na sua obra de estréia. Diferentemente de Guimarães Rosa, que apresenta com Riobaldo o personagem estilizado de um „jagunço [ou sertanejo] letrado”, Dalcídio Jurandir tematiza com Alfredo a luta de um adolescente pobre do interior pela sua formação escolar. Com isso entram em cena, detalhadamente - como em poucos outros autores brasileiros - as principais estratégias literárias de mediação. Ao mesmo tempo coloca-se em primeiro plano um problema social decisivo e que até hoje não foi resolvido de modo satisfatório: a falta de engajamento, a indiferença e a velada criação de obstáculos, por parte dos ricos e da classe culta, em relação à formação escolar dos pobres.

16 Estas considerações são apenas hipotéticas e têm aqui uma função meramente heurística. Provavelmente não houve, no caso de Guimarães Rosa, influências diretas de leitura, uma vez que nas pesquisas em sua biblioteca, no Instituto de Estudo Brasileiros da Universidade de São Paulo, verifiquei que não consta dela nenhuma obra de Dalcídio Jurandir. 


\section{AGRADECIMENTOS}

Edna Castro, Rainer Domschke e Fátima Monteiro, por suas observações e sugestões; e ao CNPq, pela bolsa de pesquisa que possibilitou a realização deste estudo.

\section{REFERÊNCIAS}

BENJAMIN, W. Origem do drama barroco alemão. Tradução Sergio Paulo Rouanet. São Paulo: Brasiliense, 1984.

BOLLE, W. (Org.). Walter Benjamin: Passagens. 1. ed. Belo Horizonte: Editora UFMG; São Paulo: Imprensa Oficial do Estado de São Paulo, 2006. v. 1.

BOLLE, W. Oficina de leitura dramática: Marajó, de Dalcídio Jurandir. In: SIMÕES, M. (Org.). Ensino, Pesquisa e Extensão: reflexões e práticas científicoacadêmicas. Belém: IFNOPAP/UFPA, p. 249-262, 2008.

CANDIDO, A. Formação da Literatura Brasileira. 2 v. Belo Horizonte: Itatiaia, 1981.

CARONE, E. A República Velha: instituições e classes sociais. São Paulo: Difel, 1970.

DE DEUS, Z. A. Dalcídio Jurandir: regionalismo, relações raciais e de poder em Marajó e Três casas e um rio. Dissertação de mestrado. Belo Horizonte: FALE/ UFMG, 2001.

DI PAOLO, P. Cabanagem: A revolução popular da Amazônia. Belém: CEJUP, 1990.

FURTADO, M. T. De reses, de homens e mulheres: as cercas do latifúndio em Marajó, de Dalcídio Jurandir. In: ASSIS, R. (Org.). Estudos comemorativos Marajó - Dalcídio Jurandir - 60 anos. Belém: UNAMA, 2007. p. 97-122.

GALLO, G. Marajó: a ditadura da água. 2. ed. Santa Cruz do Arari: Ed O nosso Museu, 1981.

GUERRA, G. Personagens e problemas em Dalcídio Jurandir: O fazendeirocoronel. Asas da Palavra, Belém, v. 8, n. 17, p. 67-73, 2004.

JURANDIR, D. (1941). Chove nos Campos de Cachoeira. 6. ed. Belém: UNAMA, 1998. . (1947). Marajó. 4. ed. Belém: EdUFPA; Rio de Janeiro: Casa de Rui Barbosa, 2008. 
JURANDIR, D. (1958). Três Casas e um rio. 3. ed. Belém: CEJUP, 1994. . (1959). Linha do Parque. 2. ed. Belém: Falangola, 1987. (1960). Belém do Grão-Pará. 2. ed. Belém: EdUFPA; Rio de Janeiro: Casa de Rui Barbosa, 2004.

Passagem dos Inocentes. São Paulo: Martins, 1963.

LEITE, L. C. M. Velha praga? Regionalismo literário brasileiro. In: PIZARRO, A. (Org.). América Latina: Palavra, Literatura e Cultura. v. 2: Emancipação do Discurso. São Paulo: Memorial; Campinas: Unicamp, p. 665-702, 1994.

LEITE, M. V. C. Fazendeiros e vaqueiragem no Marajó, de Dalcídio Jurandir. Asas da Palavra, Belém, v. 8, n. 17, p. p. 109-119, 2004.

LÖWY, M. Walter Benjamin: aviso de incêndio: uma leitura das teses "Sobre o conceito de história". Tradução das teses: Jeanne Marie Gagnebin e Marcos Lutz Müller. São Paulo: Boitempo, 2005.

MARIN, R. E. A. Ata da Audiência pública "Ocupação das terras e águas do Município de Salvaterra", lavrada em 10/maio/2005 na cidade de Salvaterra, 5 p., 2005 (cópia xerox cedida pela autora).

Marajó: tableaux de uma sociedade pós-escravista. In: LEITE, M. (Org.).

Leituras dalcidianas. Belém: UNAMA, p. 93-112, 2006a.

(Org.). Quilombolas da ilha de Marajó. Fascículo 7. In: ALMEIDA, A. W. B. de. (Coord.). Projeto Nova Cartografia Social da Amazônia. Manaus;Belém: UFAM; NAEA/UFPA; IAGUA, 2006b.

(2008). Quilombolas na Ilha de Marajó: Território e organização política. In: LIMA, M. D. de e PANTOJA, V. (Orgs.). Marajó: culturas e paisagens. Belém: $2^{\mathrm{a}}$ SR/ IPHAN, 2008. p. 163-187.

MIRANDA NETO, J. M. de. Marajó - desafio da Amazônia: aspectos da reação a modelos exógenos de desenvolvimento. 3. ed. Belém: EDUFPA, 2005.

PRESSLER, G. K. A nova recepção da obra de Dalcídio Jurandir. Asas da Palavra, Belém, v. 8, n. 17, p. 121-129, 2004.

. Dalcídio Jurandir - A Escrita do Mundo Marajoara não é regional, é universal. In: LEITE, M. V. (Org.). Leituras dalcidianas. Belém: UNAMA, 2006. p. 9-17.

SALLES, V. Chão de Dalcídio. Asas da Palavra, Belém, n. 4, p. 66-71, 1996. 
SCHWARZ, R. (Org.). Os Pobres na Literatura Brasileira. São Paulo: Brasiliense, 1983.

SPIX, J. B. von; MARTIUS, C. F. P. von. Viagem pelo Brasil, 1817-1820. Vol. III. Tradução Lúcia Furquim Lahmeyer. Belo Horizonte: Itatiaia; São Paulo: Edusp, 1981 (1ª ed. do original alemão: 1823-1831).

WALLACE, A. R. Viagens pelos rios Amazonas e Negro. Tradução Eugenio Amado. Belo Horizonte: Itatiaia; São Paulo: Edusp, 1979 (1ª ed. do original inglês: 1853). 